\title{
A Critical Review of the Types and Putative Types of Southern Asian Marine and Freshwater Fish Species in the Australian Museum Named by Francis Day
}

\author{
Carl J. Ferraris Jr., ${ }^{1}$ Mark A. MCGrouther ${ }^{2}$ And Kerryn L. Parkinson ${ }^{2}$ \\ ${ }^{1}$ Department of Ichthyology, California Academy of Sciences, \\ Golden Gate Park, San Francisco, CA 94118, United States of America \\ ferraris@CalAcademy.org \\ ${ }^{2}$ Division of Vertebrate Zoology, Australian Museum, \\ 6 College Street, Sydney NSW 2010, Australia \\ markm@austmus.gov.au \\ kerrynp@austmus.gov.au
}

\begin{abstract}
Specimens representing 160 nominal species of fishes that were named by Francis Day were among the nearly 2000 specimens sent to the Australian Museum by Day in 1884 . The type status of each of these specimens was evaluated in light of new evidence obtained from the archival papers of Edward Ramsay, the curator responsible for the acquisition of the Day collection. Of the 160 species, 141 are represented by at least one specimen that must be considered as a possible type. Approximately 126 of those species are represented by syntypes or possible syntypes, 1 by a lectotype, 2 by possible holotypes, 1 by a questionable type, and the remaining 11 by paralectotypes or possible paralectotypes. These numbers greatly exceed previous estimates of the number of types of Day's species housed in the Australian Museum and include species for which types are otherwise unknown. Among the types of Day's fishes are species from coastal marine environments from throughout southern Asia, as well as fresh and brackish water species from India, Pakistan, Afghanistan, and Myanmar.
\end{abstract}

Ferraris Jr., Carl J., Mark A. McGrouther \& Kerryn L. Parkinson, 2000. A critical review of the types and putative types of southern Asian marine and freshwater fish species in the Australian Museum named by Francis Day. Records of the Australian Museum 52(3): 289-306.

Francis Day is the single most influential figure in the ichthyology of southern Asia. During the 24 year period of his study of Asian fishes (1865 to 1889), Day named 343 species of marine and freshwater fishes, based primarily on nearly 10,000 specimens (Whitehead \& Talwar, 1976) that he obtained during nearly 20 years of intermittent field work in India and the surrounding region, which includes the area that today extends from Afghanistan to Myanmar.

Day's ichthyological pursuits, which were initially conducted in addition to his normal duties as a military surgeon, resulted in more than 50 scientific papers on southern Asian fishes, not included in which were several 
papers on fish culture and numerous government reports on aspects of Indian fisheries. His work on southern Asian fishes culminated in a massive tome generally known as "The Fishes of India" (Day, 1875-78). The book was issued in four parts (Day, 1875, 1876a, 1877c, 1878), plus one supplement (Day, 1888b), over a 13 year period, and later re-issued in an abbreviated version (Day, 1889a,b). Even now, more than 100 years after the final instalment, The Fishes of India is regarded as the most comprehensive study of the fishes of southern Asia.

Towards the end of Day's study of southern Asian fishes, he began to sell parts of his collection. Details of the extent of the sale and the purchasers of Day's fishes can be found in Whitehead \& Talwar (1976). The Australian Museum (AMS) purchased part of the collection in 1884. Although the British Museum received the largest fraction of Day's collection, the Australian Museum purchase is thought to represent the second most important fraction (after the Indian Museum, Calcutta [now Zoological Survey of India, (ZSI)]) of Day's collection in terms of the numbers of type specimens. As noted in Whitehead \& Talwar (1976), the nucleus of the collection sent to the Australian Museum was a series of specimens representing 809 species that Day placed on exhibit at the 1883 Great International Fisheries Exhibition in London. A catalogue prepared for the exhibit (Day, 1883) included a list of species displayed. The exhibit was viewed by Edward Ramsay, then Curator of the Australian Museum and representative of New South Wales to the exhibition. After the exhibition, Ramsay communicated further with Day and arranged for the purchase of the collection. According to a purchase schedule in the Australian Museum archives, the terms of the sale were for Day to send " 1000 species of fish from India and the Malay Archipelago, about 1500 specimens" to the Australian Museum for 200 pounds sterling.

As noted in Whitehead \& Talwar (1976), the list of species in the Exhibition Catalogue (Day, 1883) does not indicate that any of the exhibited specimens of species described by Day are types. In contrast, the catalogue clearly notes that exhibited specimens of some of the species named by either Bleeker or Blyth were "one of the types" or some comparable phrase. The absence of any notation regarding Day species types comes in marked contrast to such notations in the Australian Museum's Annual Report for 1884 (Anon., 1885), in which the acquisition of the Day collection was announced. Therein, the announcement of the purchase of Day's collection is followed by a five-page list of fish species names. The list is nearly identical to that found in the Exhibition Catalogue, with a few additions and deletions to the species list (along with a few corrections). Most notably, however, the list in the annual report includes the word Type, italicized and in parentheses, after many of the species named by Day. Similarly, the term "co-type" follows many of the species named by Bleeker that were not listed as one of his types in the Exhibition Catalogue. Nearly always, those species names with the terms "type", "co-type", or the phrase "One of the types", were printed in small capital letters, whereas other species names are printed in lower case letters (after the initial capital letter of the generic name). There seems to be only two likely sources of this additional information. Either Day provided Ramsay with a list of species represented by types, or Ramsay gleaned the information from Day's publications (especially Fishes of India). Our examination of correspondence from Day to Ramsay uncovered a packing list of fishes sent to AMS, which is described below (see Materials and methods). This list is similar to that in the Exhibition Catalogue and does not provide any additional information regarding the type status of any of the specimens. No additional lists were found, but Ramsay's extensive archival materials may still hold such a list.

The significance of the source of this information is that the type status of specimens as listed in the Annual Report appears to have been carried over to the registration of specimens as types and their subsequent curation as such. This has been further carried into Gilbert Whitley's draft list of types at the Australian Museum, which formed the basis of Whitehead \& Talwar's (1976) list of “possible types" of Day species.

It should be noted that two much smaller lists of additional specimens of Day's fishes, which apparently arrived at the Australian Museum in 1885 and noted in the annual report for that year (Anon., 1886), show similar annotations for species said to be represented by types. No packing lists of species were found among Ramsay's correspondence, so the source of this information cannot be considered to have been added at some later date.

Although it may not be possible to determine the original source of the claim that specimens at the Australian Museum represent types of Day's species, there is no clear evidence that they were based on information provided by Day. It became clear to us that some of the specimens listed as types were either not from the type locality, or were not of the correct size and, therefore could not be types. We chose to critically examine the status of specimens of Day species housed at the Australian Museum that were listed as types, to more carefully evaluate their actual status.

Early in the study, we discovered a specimen identified as Callichrous pabo (Hamilton), which was similar in appearance to the description of Callichrous nigrescens Day, and was from a locality consistent with the type locality of Day's species. No specimens identified as Callichrous nigrescens were listed in the Exhibition Catalogue or were sent to AMS. In the Fishes of India, the Day name was listed as a junior synonym of $C$. pabo. We suspected that the updated nomenclature in Fishes of India was applied to this specimen to make it, and all of the specimens placed in the Exhibition, consistent with the valid names in the book. Further research uncovered similar examples, so we decided to broaden our study to examine all species in which AMS received one or more specimens identified as species which included (in the Fishes of India) one of Day's species as a junior synonym. Each of these specimens was examined as a possible type of the Day species by comparing the type locality and, when provided in the original description, its size and colour pattern.

Thus, the objectives of this study were to evaluate the type status of all specimens from the Day collection that were listed as types in the 1884 Annual Report or the AMS Register, and to evaluate the possibility that other Day specimens not listed as types are, in fact, types or possible types of Day species. 


\section{Materials and methods}

Collection documentation. Several sources were consulted during this study to establish the historical record of the transfer of the collection of fishes to AMS and to evaluate the claim of type status of the specimens. A summary of the most important documents is given here.

In the Australian Museum annual report for the year 1884 (Anon., 1885: 42), an announcement of the acquisition of the Day collection is followed by a five-page list of species. The species list is in the same order in which the names are encountered in Fishes of India. Each species name is followed by the author of the name and one or more locality descriptors. Usually, the locality is a single word but, in some cases, a short phrase is used. The word "Type.", in italics and enclosed in parentheses, follows most, but not all, species described by Day. Similar notations are given about the type status for species named by Bleeker and Blyth. The term "Type", as used in the list, was defined at the top of the first page of the list as follows: "Type, that these are certified to by Dr. Day being part of his original collection, and named by him."

Specimens received by the Australian Museum were recorded in a ledger-style Register. Prior to 1885, several different general registers were used for all objects in the Museum's collections. In 1885, a separate register was initiated for the ichthyology collection, with the registration number comprising a numeric string preceded by a capital letter "I" and a full stop. Most of the fishes from Day's collection were apparently assigned a registration number prior to ichthyology starting a separate lettering system, and nearly all Day specimens have a registration number beginning with a " $\mathrm{B}$ ". The first registration of Day fishes was found to be B.3019, entered in July, 1884. A series of 35 specimens, apparently all stuffed specimens, were registered in sequential order. The bulk of the collection, the fluid preserved specimens, were entered into the " $\mathrm{B}$ " register in 1885 by J. D. Ogilby (Paxton \& McGrouther, 1996), but some specimens were registered later in the "I" series. Registration of the stuffed specimens was rudimentary. In most cases, the scientific name of the species and "India" (or ditto marks) were the only data listed. A few entries included a more precise locality, but some lines in the register were completely blank. In contrast, the registration of the fluid collection contained more detailed locality information as well as an indication that certain specimens were types. The species names and locality information were the same as that found in the 1884 Annual Report, although the species were not listed in the same order. Specimens indicated as types in the annual report were noted as such in the register, and additional specimens were recorded as types in the register.
In the New South Wales State Library archives, Edward Ramsay's correspondence from Francis Day includes a 22 page printed list of fishes, entitled:

DIVISION LI.

SPECIMENS OF FISH FROM INDIA AND THE INDIAN OCEAN. EXHIBITED BY

DEPUTY SURGEON-GENERAL FRANCIS DAY, F.L.S., F.Z.S.

This list appears to be either part of the proof sheet for the Exhibition Catalogue (Day, 1883; referred herein as the Catalogue), or an offprint (with different pagination) of that portion of the Catalogue. The Catalogue and the printed list found with Ramsay's correspondence are identical, except for the pagination. However, the list in the Ramsay archives was annotated, presumably in Day's hand, with additional species names, crossed-out species names and, on the left margin of some of the names, a numeral between 2 and 10. On the last page there is a handwritten note, only partially legible but clearly signed by Day, in which Day certified that "seven hundred and eighty six species" were delivered to the New South Wales Commission. Thus, the list appears to be a packing list that Day prepared to accompany the shipment of specimens. The handwritten numeral indicates the number of specimens shipped, for those species represented by more than one specimen (the entry for one species states "many" rather than a definite number). This annotated packing list was clearly the basis of the list produced in the 1884 Annual Report. However, the packing list did not indicate type status of Day's species (although some species were said to be types of either Bleeker or Blyth species). A photocopy of the packing list is now in the AMS Ichthyology Section files.

At some time, a systematic cross index of the AMS collection was prepared on three inch by five inch index cards. The cards for the Day collection appear to have been prepared by one person, as the handwriting is distinctive and identical. The handwriting does not match that of the labels in the jars (see below) or that in the register. Each card included the name and locality of the specimen, the registration number, and a type indication. All of these data appear to be identical to the information in the register, and the cards may have been generated directly from the register. However, the cards also include the size of the specimens, which was not found in the register or in any of the early jar labels. Some of the cards contain annotations in different handwriting: primarily re-identifications. The card file was used by us in several ways. We were able to determine whether a specimen was registered in a different part of the register, the originally recorded size of the specimens, and redeterminations of specimens that were not listed as types. 
Another source of information about the Day specimens was the labels inside jars. Several types of labels were found associated with specimens from Day's collection. Some labels defy classification, but most can be placed into one of relatively few groups. In order of decreasing significance, the label types are:

1 Original specimen label, type 1 (Fig. 1): This label appears to be the one that accompanied the specimen when it was transferred from Day to AMS. The label is characterized by being of small size (approximately 20 by $30 \mathrm{~mm}$ ), on thin paper, and with two solid horizontal lines, one running above and one below the middle of the label. In between the lines, in a small neat script, is written the scientific name and an abbreviated locality for the specimen (usually one word). The writing was often faded, but usually readable.

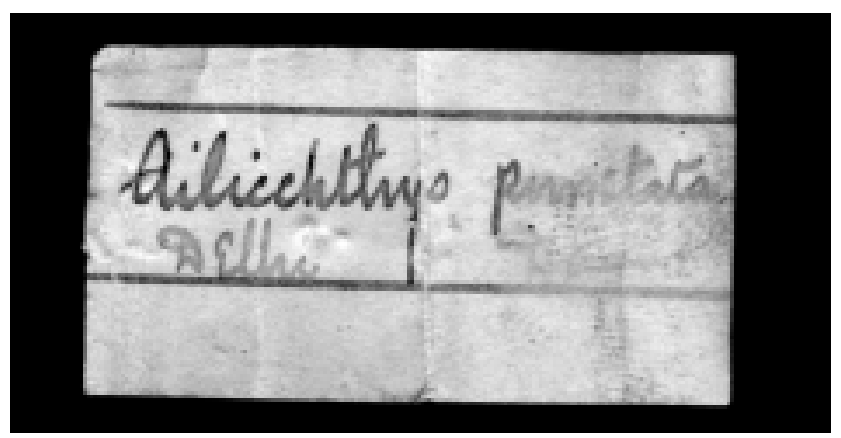

Figure 1. Original Specimen label Type 1. Ailiichthys punctata AMS B.7570.

Original specimen label, type 2 (Fig. 2): This label appears to have been an alternate label to the type 1 label, as the two were not found together in any jar. This label is characterized by its small size (about 20 by $40 \mathrm{~mm}$ ), with three dotted horizontal lines that are approximately equally spaced from top to bottom across one side of the label. The script is small, but of a different style from that of the type 1 label. Writing was found above the middle and lower lines. However, the writing is badly faded, and in many cases there is virtually nothing left to read. When readable, it appears that the information is the same as that of the type 1 label; i.e., the scientific name and a one-word locality. These labels were either torn or there are signs of tiny holes in one corner of the label, suggesting that the label was initially sewn to the specimen. No specimens were found, however, with labels of this type sewn on.

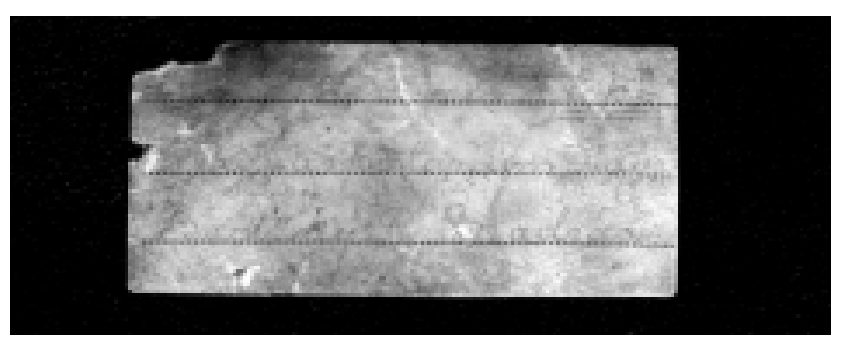

Figure 2. Original Specimen label Type 2. Glyptosternum madraspatanum AMS B.8004.
2 Copy of the original specimen label (Fig. 3): This label appears to be intended as an enlarged copy of the original label. The type and quality of the paper for this second label varies, but is usually an elongate piece of white paper of about 25 by $100 \mathrm{~mm}$. The information is written in pencil in a script that is different from, and much larger than, that of either original label. This kind of label was either rolled up into a cylinder and tied with a fine thread, or wrinkled as if it had previously been tied up and now partially or completely unrolled. In some cases, the rolledup label also had a metal tag bearing an impressed AMS registration number tied together with it (in some other specimens, the metal tag was tied directly to the fish, usually through the lower jaw). In a few instances, an original label, of either type 1 or type 2 , was also found rolled up within the rolled-and-tied copy. The label contains the scientific name, one-word locality, and in addition, the author of the name. The text of this type of label was almost always readable, because of the size of the script and the use of pencil. This type of label appears to have been written at the time that the specimen was registered. This is inferred by the presence of labels with metal tags joined together. It is not likely that the tags were issued first, then removed from some specimens and attached to the paper labels. In addition, as will be noted below, subsequent labels usually include the registration number, and the absence of this information suggests that the number was not previously assigned.

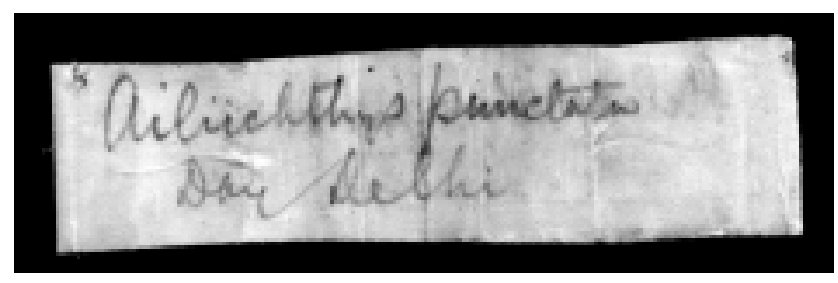

Figure 3. Copy of the Original specimen label. Ailiichthys punctata AMS B.7570.

3 Jar label(s) (Fig. 4): Most jars have one or more handwritten labels that appear to have been intended as a jar label, i.e., a label meant to be readable through the specimen container. These labels were written in pencil, and they appear to have been written by the same hand as the rolled-up copy (label 3, above). However, the paper was not folded or rolled. The information on the label varied. In many cases, only the scientific name of the specimen was written. In others, the registration number, author of the name, and an indication that the specimen was a type were variably included. It is possible that this category represents several generations of labels, but only rarely was more than one such label found together in a jar.

4 Subsequent jar labels: A variety of preprinted label forms, filled out in pencil, India-ink pen, or type-written (or a combination of media) exists in various combinations. In addition, computer-generated labels were prepared for all containers within the past decade. These labels often include information beyond that found in the early specimen labels or in the register, including changes in specimen 


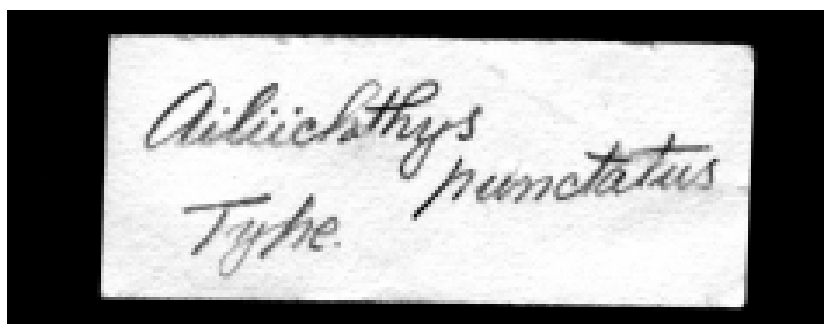

Figure 4. Jar label. Ailiichthys punctata AMS B.7570.

identification, updated localities, etc., most of which was not relevant to the question of whether the specimens represent types.

Identification of specimens as types. Because Day did not clearly identify specimens as types of his species, subsequent attempts to do so, such as ours herein, must be based on evidence that Day examined the specimen and considered it to be a member of his new species prior to its description. The criteria we used are as follows. Any specimen sent to AMS that arrived identified as a Day species was considered as a potential type of that species. In addition, any specimen that was identified as a valid species in Day's Fishes of India which included in its synonymy a species named by Day was considered as a potential type of the synonymized species. Each of the specimens that fit one of the two criteria mentioned above was compared against the locality and size of specimens examined in the original description. In many cases, Day was vague about the type locality of his species. When a specimen was found to have come from a locality that was consistent with a vaguely-worded type locality, we attempted to determine whether Day had visited (or received specimens from) the specimen locality prior to the publication of the species description. Finally, specimens were compared to the species account and illustration in the original description and the account in the Fishes of India for obvious discrepancies. More detailed comparison between the description and specimens was beyond the scope of this study. A specimen found to be consistent with the locality, collection date, size and description was listed below as a type. Most often, Day's species were described from a series of specimens, without an explicit holotype designation. We did not make an exhaustive search of the literature to determine whether lectotypes were designated for these species and, instead, referred to these specimens as syntypes unless we were aware of a valid lectotype designation. We did not attempt to verify all lectotype designations reported in Eschmeyer (1998), but we did list an AMS specimen as a paralectotype if Eschmeyer listed another specimen as the lectotype.

In a few cases, a specimen that fits our criteria for inclusion as a type increased the number of specimens claimed as possible types (Whitehead \& Talwar, 1976) beyond the number of specimens stated in the original description of the species. In these cases, we referred to the specimen as a possible type and discussed the issue in the remarks.
All specimens considered by us as potential types are listed below, even if they were later determined not to qualify as types. It is possible that we misinterpreted the relationship between the stated type locality and the locality given for the specimen, and that a specimen rejected by us as not having come from the type locality may indeed qualify. Similarly, specimens not found by us during this study are listed below, as our search of the AMS collection was an extensive, but not an exhaustive one.

Data presentation. Species accounts are listed alphabetically by species name, similar to that in Eschmeyer (1998). For each of the species discussed, the following information is presented. The species name is the original spelling of the name, except that capital letters of the specific name have been changed to lower case. If a subgeneric name was used in the heading of the species account, that name is included. A subgeneric name mentioned elsewhere, either in the body of the species account or elsewhere in the text, is not added. The year of the original description follows Eschmeyer (1998) and details on the precise date of publication may be found therein. Type locality is stated exactly as given in the original description. When necessary for clarity, additional information about the type locality that was found elsewhere in the paper is added in brackets. The AMS registration number is given, followed by the number of specimens and size, or range of sizes, in parentheses, for each registration number. Specimen sizes are reported as standard length, in millimeters, except that total length (TL) is used for eels and sharks. Specimens that do not have a length were either not found during this study, or were on loan. We often repeat the size of the specimen(s) reported in the original description of the species for comparison with the AMS specimen(s). Early on, Day (1865c) stated that he reported the size of fish as total length, in inches and fractions thereof. Subsequently, he did not clearly state his measurement technique, but we think he continued to use total length throughout his career. The locality for each specimen is taken from specimen labels, when possible, or from the register. Localities stated in bold face are those taken from the original specimen label or the copy of that label (see Materials and methods for details). The section entitled Remarks include our interpretation of the type status of the specimen(s), as well as interpretations in published accounts of the specimens. Published comments on the status of the species name are included when the AMS specimen was among the specimens examined. A more extensive summary of the status of many of the species' names can be found in Eschmeyer (1998).

\section{Results}

Specimens of 102 species of fishes that were described by Francis Day were reported to be represented in the collection of the Australian Museum (Whitehead \& Talwar, 1976). In addition, our search of the literature indicated that specimens that might represent unrecognized types of an additional 57 species were registered at AMS. During this study, specimens were found for all but 11 of these species. Three of the remaining 11 species were recorded in the 1884 
Annual Report as having been received by AMS, but the specimens appear never to have been registered. This suggests either that they never actually were sent to the Museum, or they arrived but were overlooked. One of the missing 11 specimens was recorded in the register as having been considered lost in 1930. The fate of the remaining seven specimens is unclear.

The list below represents all species described by Day for which AMS has at least one specimen, or for which a specimen was listed by Day in his packing list. Of the 160 species listed, we concluded that 143 are represented by at least one type specimen. One of those species is represented by a lectotype, 127 by syntypes or possible syntypes, 3 by possible holotypes and the remaining 12 by paralectotypes or possible paralectotypes. These numbers must be somewhat tentative, however, as we did not make an exhaustive search of possible lectotype designations, and it is likely that some of the specimens we regard as syntypes are actually lectotypes or paralectotypes.

Arius acutirostris Day, 1877c: 459, pl. 107, fig. 1. Type locality: Salwein River at Moulmein in Burma. NON-TYPE: AMS B.7733 $(1,80 \mathrm{~mm})$ Irrawaddy. Remarks: The AMS specimen has been considered a type following the notations in the 1884 Annual Report and the register. However, the specimen was not collected in the Salween River, the only locality mentioned in the original description. Therefore, the specimen cannot be considered to be part of the type series.

Pseudeutropius acutirostris Day, 1870d: 618. Type locality: Throughout Burma. SYNTYPE: AMS B.7967 (1, $79 \mathrm{~mm})$ Burma. Remarks: Day reported that the species "rarely exceeds 4 inches" (101.6 mm), which is larger than the AMS specimen.

Salarias alboguttatus Day, 1876a: 334. Type locality: Andaman Is. SYNTYPE: AMS B.7497 (1) Andamans. Remarks: This name is preoccupied by Salarias alboguttatus Kner, 1867, and was replaced by Salarias dayi Whitley, 1929. Therefore, this specimen is also a syntype of Whitley's species. We were unable to locate this specimen.

Barbus ambassis Day, 1869a: 583. Type locality: Kurnool, in Madras, and Arcot. SYNTYPE: AMS B.7553 (1, $32 \mathrm{~mm})$ Madras. Remarks: Day indicated that he examined specimens up to " $23 / 10$ inches" ( $58.4 \mathrm{~mm}$ ) in total length.

Arius andamanensis Day, 1871a: 699. Type locality: Andamans. SYNTYPE: AMS B.7931 (1, $187 \mathrm{~mm})$ Andamans. Remarks: Subsequent to the description of this species, Day (1875-78) placed that name in the synonymy of Arius thalassinus (Rüppell). In his report on Andaman fishes, Day (1871a) did not list $A$. thalassinus among the species examined, which suggests that the only Andaman specimens of $A$. thalassinus he examined were his $A$. andamanensis types. The specimen arrived at AMS identified as Arius thalassinus, from the type locality of $A$. andamanensis. Kailola (1986: 546) identified this specimen as Arius bilineatus (Valenciennes, 1840), but she concluded that it was not conspecific with a specimen at ZSI also identified by Day as A. andamanensis.

Gobius andamanensis Day, 1871a: 691. Type locality: Brackish water in the Andamans. SYNTYPE: AMS B.8030 (1, $90 \mathrm{~mm})$ Andamans. Remarks: Subsequent to the description of this species, Day (1875-78) placed that name in the synonymy of Gobius puntang Bleeker. The specimen deposited at AMS was identified by that name and listed as a co-type of Bleeker's species in the annual report (but not in Day's packing list). However, the specimen is from the type locality of Gobius andamanensis and should be considered as a syntype of that species.

Salarias andamensis Day, 1870c: 611. Type locality: Mundakhari
Bay, Andaman Is. Possible SyntyPe: AMS B.8062 (1) Andaman Is. Remarks: Day indicated that he examined four specimens. Springer \& Williams (1994: 30) concluded that the type series was lost and designated a neotype (USNM 112032). However, they did not mention the AMS specimen and apparently did not know of its existence. The AMS specimen was not found during the course of this study.

Exostoma andersonii Day, 1870a: 524. Type locality: Hotham [=Hotha] and Ponsee, China. PossiBle SYNTYPE: AMS B.8081 $(1,127 \mathrm{~mm})$ "Bhamo, China." Remarks: This specimen was cited in Day's packing list with the enigmatic citation: "Exostoma andersonii Do. Bhamo, China." The "Do." implies a repeat of the author of the previously listed species, which was Pseudecheneis sulcatus McClelland. However, Exostoma andersonii was described by Day, as noted above. In addition, the citation of "Bhamo, China" is peculiar inasmuch as, even during Day's time, Bhamo was a city of Upper Burma. Thus, it appears that the information about this species in Day's listing was not carefully edited. Anderson (1879) reported that the only specimens of this species taken during his two expeditions to Burma and China were the four on which Day based his description of E. andersonii, and Day (1875-78) did not indicate that he examined any additional specimens. Whitehead \& Talwar (1976) indicated that only two of the original four specimens deposited at ZSI were found. Therefore, the specimen at AMS may well be one of Day's type specimens.

Barbus arenatus Day, 1878: 574, pl. 142, fig. 7. Type locality: Madras. SYNTYPE: AMS B.7906 (1, $82 \mathrm{~mm})$ Madras. Remarks: Day was vague about the number of specimens examined. However, he clearly indicated that more than one specimen was studied, by the statement: "in some examples a darkish band...."

Chela argentea Day, 1867a: 301. Type locality: Bowany River. PARALECTOTYPE: AMS B.7881 (1, $109 \mathrm{~mm})$ Bowany. Remarks: Day reported that he examined specimens up to " $52 / 8$ inches" (133.4 mm). See Eschmeyer (1998) for information on lectotype designation.

Panchax argenteus Day, 1868a: 706. Type locality: Near Madras. SYNTYPE: AMS B.7492 (1) Madras. Remarks: Subsequent to the description of the species, Day (1875-78) placed the name in the synonymy of Haplochilus melastigma (M'Clelland, 1839). The 1884 Annual Report lists $H$. melastigma from Madras among the species received from Day's collection. The AMS specimen was not found during this study, so it was not possible to determine whether it is within the " $4 / 5$ to $12 / 10$ inch" ( 20.3 to $30.4 \mathrm{~mm}$ ) range listed by Day.

Macrones armatus Day, 1865b: 289, unnumbered fig. Type locality: Rivers and occasionally in backwaters, Cochin. NON-TYPE: AMS B.7573 (1, $76 \mathrm{~mm}$ ) Canara. Remarks: Although this specimen was listed in the AMS register as a type of Macrones armatus, the locality associated with the specimen is remote from the stated type locality of the species. Day (1870f: 370) stated that he received specimens of Macrones armatus from Mangalore [South Canara] in 1870. It is likely that one of these specimens was sent to AMS.

Clarias assamensis Day, 1877c: 485. Type locality: Goalpara and as high as Suddya [Assam]. SYNTYPE: AMS B.7485 (1, 208 mm) Assam.

Perilampus aurolineatus Day, 1865b: 306. Type locality: In rivers and stagnant tanks [Cochin, India]. SYNTYPE: AMS B.7834 (1) Malabar. Subsequent to the description of the species, Day (1875-78) placed the name in the synonymy of Danio malabaricus (Jerdon). The locality of the specimen is vague, but represents a region that includes the type locality. However, the specimen is joined together by a string sewn through its mouth to a second specimen, AMS B.7835, from the Shevaroy Hills. The locality of this second specimen is outside of the region of Cochin and, therefore it cannot be considered a type. It is not possible to unambiguously associate a registration 
number with either of these specimens as the metal tags are attached to the string and not to the specimens. There are no handwritten labels to refer to either. Therefore, it may not be possible to determine which of the two specimens is the syntype.

Barilius bakeri Day, 1865b: 305. Type locality: Mundikyum [Cochin, India]. NON-TYPE: AMS B.7916 (1, $87 \mathrm{~mm})$ Travancore Hills. Remarks: Day indicated that he examined "several" specimens ranging from $4 \% 10$ to $5 \frac{1}{10}$ inches (116.8 to $129.5 \mathrm{~mm}$ ) in total length. The locality listed for the specimen is the general region within which Mundikyum, the type locality, is found.

Rohtee bakeri Day, 1873b: 240. Type locality: Cottayam. PossiBLE SYNTYPE: AMS (registration number unknown), Cottayam. Remarks: This species was listed in the 1884 Annual Report as having been received by AMS. However, we have not found a listing for the species in the register, card file, or database. Day indicated that he examined three specimens of this species, up to " $4 \frac{1}{2}$ inches" $(114.3 \mathrm{~mm})$ in length. Whitehead \& Talwar (1976) accounted for only one of the three specimens at ZSI.

Caranx bidii Day, 1873b: 237. Type locality: Madras. SYNTYPES: AMS B.8057 (2, 103-128 mm) Madras. Remarks: Subsequent to the description of this species, Day (1875-78) placed the name in the synonymy of Caranx leptolepis Cuvier (1833). The specimens sent to AMS were identified as Caranx leptolepis, from the type locality of $C$. bidii.

Apocryptes bleekeri Day, 1876a: 300, pl. 64, fig. 3. Type locality: Seas of India to the Malay Archipelago. SYNTYPE: AMS B.7501 (1, $58 \mathrm{~mm})$ Madras. Remarks: Day (1873a: 109) initially identified specimens from Madras, Bombay, and Kurrachee as "Apocryptes madurensis ? Bleeker." He later concluded that his specimens were not conspecific with Bleeker's species and that they represented a new species (Day, 1876a). In the description of A. bleekeri, Day listed his account of $A$. madurensis (Day, 1873a) in the synonymy. Therefore, the specimens that were examined for the 1873 paper are part of the type series of Apocryptes bleekeri. As the specimen at AMS is from one of the localities listed in the 1873 paper, it is considered here to be one of the types. This specimen was identified by Murdy (1989: 9) as Apocryptodon madurensis (Bleeker, 1849).

Barilius (Pachystomus) bleekeri Day, 1872a: 5. Type locality: A river at Gangrete which joins the Beeas in the Sub-Himalayan range. SYNTYPE: AMS B.7827 (1, 97 mm), Kangra. Remarks: Subsequent to the description of this species, Day (1875-78) placed the name in the synonymy of Barilius vagra (Hamilton). The specimen sent to AMS was identified as Barilius vagra, and the stated locality of the specimen is a region that includes the type locality of Day's species.

Macrones bleekeri Day, 1877c: 451, pl. 101, fig. 1. Type locality: Originally "Sind, Jumna, upper waters of the Ganges, and Burma", now restricted by lectotype designation to Jumna River. PARALECTOTYPE: AMS B.7999 (1, 109 mm) Seharunpore. Remarks: The lectotype was designated in Roberts (1994), wherein the species was considered to be valid as Mystus bleekeri.

Scorpaena bleekeri Day, 1878: 747. Type locality: Andamans to Malay Archipelago. SYNTYPE: AMS B.8277 (1, $147 \mathrm{~mm})$ Karachi. Remarks: Day illustrated this species, as Scorpaena haplodactylus, on pl. 36, fig. 2 of Fishes of India (Day, 1875). This name was proposed in the corrigenda of Fishes of India to provide a new name for the species previously described and illustrated as Scorpaena haplodactylus Bleeker (Day, 1875: 149, pl. 36, fig. 2), an identification that Day subsequently determined to be incorrect. Among the specimens received by AMS was one labelled Scorpaena aplodactylus from Batavia (AMS B.7729) which appears to correspond to a specimen mentioned in the 1884 Annual Report as a "type from Bleeker's collection." A second specimen identified as Scorpaena aplodactylus, from Karachi (AMS B.8277), is likely to be one of the specimens examined by Day in preparation of his account of Scorpaena haplodactylus Bleeker and, therefore, a part of the type series of Scorpaena bleekeri.

Chela boopis Day, 1874: 708. Type locality: South Canara. SYNTYPE: AMS B.7820 (1, 95 mm) Canara. Remarks: Day indicated that he examined specimens of this species up to "5 inches" (127 mm) in length.

Barbus bovianicus Day, 1877c: pl. 138, fig. 1 (text issued in Day, 1878: 566, as Barbus bovanicus [sic]). Type locality: Bowany River at base of Neilgherry hills in Madras (taken from Day, 1878: 566). SYNTYPE: AMS B.7829 (1, $98 \mathrm{~mm}$ ) Bowany. Remarks: Day indicated that he examined specimens up to "5 inches" (127 mm) in length.

Semiplotus brevidorsalis Day, 1873b: 239. Type locality: Rivers below Neilgherry Hills, in the Madras Presidency. SYNTYPE: AMS B.7808 (1, $183 \mathrm{~mm})$ Madras.

Otolithus brunneus Day, 1873c: 524. Type locality: Bombay. PARALECTOTYPES: AMS B.8193 (1, $173 \mathrm{~mm})$ Bombay and B.8194 (1, 205) Bombay. Remarks: See Eschmeyer (1998) for information on the lectotype designation.

Amblyopus buchanani Day, 1873a: 110. Type locality: Calcutta. SYNTYPE: AMS B.7583 (1, 204 mm) Calcutta. Remarks: This specimen arrived at AMS identified as Gobioides buchanani, following the nomenclature in Day (1875-78). Day indicated that he examined specimens up to "11 inches" $(279.4 \mathrm{~mm})$ in length.

Cynoglossus buchanani Day, 1870a: 522. Type locality: no locality stated. POSSIBLE SYNTYPE: AMS B.7785 (1) Madras. Remarks: Subsequent to the description of this species, Day (1875-78) placed the name in the synonymy of Cynoglossus hamiltonii Günther. Day stated that he based his description on two specimens in the Calcutta Museum, but gave no information on the provenance of the specimens. This may indicate that there was no locality information associated with the specimens or that the locality was accidentally overlooked in Day's account. Whitehead \& Talwar (1976) reported that the Register at the Zoological Survey of India indicates one missing lot (A 463) for that species, but they give no indication of whether more than one specimen was included in the lot. Thus, it is possible, but not likely, that the AMS specimen represents one of the two types of this species.

Nangra buchanani Day, 1877c: 494, pl. 113, fig. 3. Type locality: Ganges, Jumna, and Indus rivers; Delhi, India. SYNTYPE: AMS B.7541 (1, $44 \mathrm{~mm})$ Indus. Remarks: It is not clear from the original description whether this name should be considered a new name, with its own types, or a replacement for Pimelodus nangra Hamilton, in order to avoid the tautonomy caused by Day's use of Nangra as a generic name. If it is a new name, the specimen noted above should be considered a type.

Dangila burmanica Day, 1877c: 546, pl. 131, fig. 2. Type locality: Moulmein and Tavoy. SYNTYPE: AMS B.7854 (1, $130 \mathrm{~mm})$ Moulmein. Remarks: Day indicated that he examined specimens up to "10 inches" (254 mm) in length.

Olyra burmanica Day, 1872d: 711. Type locality: Pegu Yomas [Burma]. SYNTYPE: AMS B.7560 (1,41 mm) Pegu. Remarks: Day indicated that he examined two specimens of this species. Whitehead \& Talwar (1976) did not uncover the second specimen in any of the museums they surveyed.

Arius burmanicus Day, 1870d: 618. Type locality: Irrawaddi, Bassein district, and Salwein in the Tenasserim provinces. SYNTYPE: AMS B.7520 (1, $270 \mathrm{~mm}$ ) Moulmein. Remarks: Moulmein is a large city at the mouth of the Salween River. Day did not provide any indication of the number or the size of the specimens examined.

Barbus burmanicus Day, 1878: 572, pl. 141, fig. 4. Type locality: Burma, the example (figured life size) was from Mergui. Possible SYNTYPE: AMS B.7898 (1, $104 \mathrm{~mm})$ Pegu [Burma]. Remarks: This specimen was not listed as a type in the 1884 
Annual Report, but it was so listed in the register. The stated type locality of the species is not very informative, except that it appears that Day found the species in more than one place in Burma. The locality of the AMS specimen is among the Burmese localities visited by Day (1870d).

Eleotris canarensis Day, 1876a: 313, pl. 69, fig. 2. Type locality: Mangalore. SYNTYPE: AMS B.8271 (1) Canara. Remarks: The stated locality of this specimen is a region within which Mangalore, the type locality of the species, is found.

Etroplus canarensis Day, 1877c: 414, pl. 89, fig. 5. Type locality: South Canara. SYNTYPE: AMS B.8148 (1,63 mm) Canara. Day indicated that he examined specimens "to at least $4 \frac{1}{2}$ inches" (114.3 mm) in length.

Apocryptes cantoris Day, 1871a: 693. Type locality: Andaman Is. NON-TYPE: AMS B.8336 (1, 46 mm) Madras. Remarks: This specimen arrived at AMS identified as Apocryptichthys cantoris, following the nomenclature in Day (1875-78). It has been listed in the register as a type, but the stated locality for the specimen does not match the type locality. Therefore, this specimen should not considered to be part of the type series.

Nemacheilus chryseus Day, 1873c: 529. Type locality: Bowany River. SYNTYPE: AMS B.7489 (1, 36.8 mm) Bowany. Remarks: Subsequent to the description of this species, Day (1875-78) placed the name in the synonymy of Nemachilus [sic] beavani Günther. The specimen was sent to AMS identified as Nemachilus [sic] beavani from the type locality of Nemacheilus chryseus.

Pseudobagrus chryseus Day, 1865b: 290. Type locality: Kurriavanoor River; backwater at Kurriapudnam and river at Cochin, India. POSSIBLE SYNTYPE: AMS B.7922 (1, $175 \mathrm{~mm})$ Malabar. Remarks: The specimen received at AMS was identified as Macrones chryseus, following the nomenclature in Day (1875-78) and listed as a type specimen in the register. Day (1865b) lists several localities from which he saw specimens, and stated that the species was "exceedingly common". However, Day's account implies that only one specimen was examined, as he stated that the "length of specimen $62 / 10$ inches" $(157.5 \mathrm{~mm})$ and the proportional measurements were not presented as ranges of values. Eschmeyer (1998) concluded that only one specimen was studied, which would make that specimen the holotype. The specimen at AMS is too small to be the measured specimen. It is therefore either a syntype or, if the measured specimen is a holotype, not a type.

Serranus coromandelicus Day, 1878: 746. Type locality: Seas of India to the Malay Archipelago. SYNTYPE: AMS B.8272 (1, $270 \mathrm{~mm}$ ) Madras. Remarks: This name is a replacement for Epinephelus dayi Bleeker, 1875, which is preoccupied by Epinephelus dayi Bleeker, 1873. Bleeker (1875: 47) proposed a new name for the species described and illustrated in Day (1875: 12, pl. 8, fig. 1) as Serranus waandersi Bleeker. Therefore, the types of Epinephelus dayi Bleeker, 1875, and its replacement, Serranus coromandelicus, are all of the specimens that Day considered in the preparation of his account of Serranus waandersi. Day's account of Serranus waandersi clearly indicates that more than one specimen was examined, as a range of body and eye proportions and lateral line scale counts are given. Therefore, the Serranus coromandelicus must be considered to have been based on a series of syntypes and not, as Randall \& Heemstra (1991) and Eschmeyer (1998) concluded, a holotype. The 1884 Annual Report lists Serranus coromandelicus as a species received from the Day collection and must be considered a syntype.

Euctenogobius cristatus Day, 1873a: 109. Type locality: Bombay and Madras. SYNTYPE: AMS B.8198 (1, $90 \mathrm{~mm})$ Bombay. Remarks: Day indicated that he examined specimens of this species up to "5 inches" (127 mm) in length, but did not specify the number of specimens in his possession.
Chrysophrys cuvieri Day, 1875: 141, pl. 34, fig. 3. Type locality: Seas of India. SYNTYPE: AMS B.8225 (1, $129 \mathrm{~mm})$ Madras. Remarks: Day did not indicate how many specimens he examined, but reported that the largest specimen was " $141 / 2$ inches" $(368.3 \mathrm{~mm})$ in length. He gave no indication of the provenance of his specimens, except that the figured specimen was from Mangalore. Thus, we base our conclusion on the type status of this specimen on the original identification label.

Labeo denisonii Day, 1865b: 299. Type locality: Mundikyum. SYNTYPE: AMS B.7913 (1, 89 mm) Travancore Hills. Remarks: This specimen was received at AMS identified as Barbus denisonii, following the nomenclature in Day (1875-78). Day indicated that he examined several specimens for the description of this species, ranging from 4 to $5 \frac{1 / 10}{10}$ inches (101.6 to 129.5 $\mathrm{mm}$ ) in total length. The stated locality for the specimen is the general region within which Mundikyum, the type locality, is found.

Nemacheilus denisoni Day, 1867a: 287. Type locality: Bowany River. NON-TYPE: AMS B.7507 (1, $57 \mathrm{~mm})$ Wynaad. Remarks: Apparently Day received specimens from the Wynaad only after the description of this species (Day, 1867b).

Cynoglossus dispar Day, 1877c: 434, pl. 96, fig. 2. Type locality: Bombay and Madras. NON-TYPES: AMS B.7941 (1) and AMS B.7942 (1) both from Sind. Remarks: The specimens noted here were listed as types in the 1884 Annual Report, but they were not collected in Bombay or Madras, the only localities which Day mentioned in his original description. Therefore, the specimens cannot be considered to be part of the type series.

Barbus (Barbodes) dobsoni Day, 1876b: 574. Type locality: [Deccan, India]. SynTYPE: AMS B.7860 (1, $62 \mathrm{~mm})$ Poona. Remarks: No locality was stated in the account of this new species. The paper was concerned only with fishes of the Deccan, a region of India that includes Poona. The locality of the specimen sent to AMS is consistent with the inferred type locality of the species.

Puntius (Barbodes) dubius Day, 1867a: 291. Type locality: Bowany River. SYNTYPE: AMS B.7608 (1, 173 mm) Bowany. Remarks: This specimen was received at AMS identified as Barbus dubius, following the nomenclature in Day (1875-78). Day gave no indication of the number of specimens examined or their size.

Barbus dukai Day, 1878: 564, pl. 143, fig. 3. Type locality: Teesta River, Darjeeling. SYNTYPE: AMS B.7893 (1, $84 \mathrm{~mm})$ Darjeeling. Remarks: Day was unclear about the number of specimens he examined and only indicated that he obtained "several examples" of this species.

Silurus dukai Day, 1873b: 239. Type locality: Darjeeling. SYNTYPE: AMS B.7571 (1, $87 \mathrm{~mm})$ Darjeeling. Remarks: Subsequent to the description of the species, Day (1875-78) placed the name in the synonymy of Silurus afghana Günther. The specimen arrived at AMS identified as Silurus afghana from type locality of Silurus dukai.

Callichrous egertonii Day, 1872d: 710. Type locality: Subhimalayan range in the Punjaub. SYNTYPE: AMS B.8065 (1, $146 \mathrm{~mm}$ ) Sind. Remarks: Subsequent to description of this species, Day (1875-78) placed that name in the synonymy of Callichrous pabda (Hamilton). The specimen arrived at AMS identified as $C$. pabda. The locality given for the specimen is vague, but it is consistent with the stated type locality of the species.

Apogon ellioti Day, 1875: 63, pl. 17, fig. 1. Type locality: Originally "east coast of Africa to China and Japan", restricted to Madras by lectotype designation. POSSIBLE LECTOTYPE OR PARALECTOTYPE: AMS B.8226 (1, $60 \mathrm{~mm}$ ) Madras. Remarks: Day indicated that he examined two specimens "up to 4 inches" (101.6 mm) in length, but Whitehead \& Talwar (1976) recorded a total of four putative types of this species, in the collections of ZSI, AMS, and RMNH. Gon (1997: 188) selected the 
"illustrated specimen" as lectotype, and followed Whitehead \& Talwar's (1976) statement that the illustrated specimen was one of the two specimens at ZSI. From the text of Gon's paper it is not clear whether he examined the ZSI specimens and compared them to the published illustration, or based his conclusion solely on Whitehead \& Talwar. Because of this, we consider the question of which of the four potential types is actually the lectotype to be unresolved.

Solea elongata Day, 1877c: 426, pl. 90, fig. 4. Type locality: Madras. POSSIBLE SYNTYPES: AMS B.8278-79 (2, 34-48 mm) Madras. Remarks: Day stated that he examined only two specimens when he described this species. The 1884 Annual Report lists Solea elongata, from the type locality, among the included species. However, Whitehead \& Talwar (1976) report three specimens from the Day collection at ZSI (now all lost). Thus, the type status of the specimens at AMS is uncertain.

Barilius evezardi Day, 1872b: 326. Type locality: Púna. PossiBle SYNTYPE: AMS B.7895 (1, 93 mm) Poona. Remarks: Day indicated that he examined three specimens of this species, up to " $4 \frac{1}{2} 2$ inches" $(114.3 \mathrm{~mm})$ in length. Whitehead \& Talwar (1976) indicated that at least five museums possess specimens of this species from Day's collection.

Upeneoides fasciolatus Day, 1868c: 151. Type locality: Madras, India. POSSIBLE SYNTYPE: AMS B.8186 (1, $120 \mathrm{~mm})$ Madras. Remarks: Subsequent to the description of this species, Day (1875-78) placed the name in the synonymy of Upeneoides sulphureus (Cuvier, 1829). The specimen mentioned above was sent to AMS identified as $U$. sulphureus from the type locality of Upeneoides fasciolatus. However, in the original description of the species, Day provided the following statement: "Length of specimen 3 inches" (76.2 mm). This may indicate that Day had only one specimen, as was concluded in Eschmeyer (1998), or that the best or largest specimen was that size. The specimen at AMS is substantially larger than 3 inches $(76.2 \mathrm{~mm})$ and therefore, not the specimen referred to by Day. However, because the specimen came from the type locality, and as Day did not indicate clearly whether he had only one specimen, we cannot exclude it from consideration as a part of the type series, and instead, list it as a possible syntype.

Boleophthalmus glaucus Day, 1876a: 306, pl. 65, fig. 3. Type locality: Andamans. SYNTYPE: AMS B.8121 (1, $128 \mathrm{~mm})$ Andamans. Remarks: This specimen was not indicated as a type in the 1884 Annual Report. Murdy (1989: 50) identified the specimen as Scartelaos cantoris (Day, 1871a) and placed Boleophthalmus glaucus in the synonymy of that species.

Sciaena glaucus Day, 1876a: 192, pl. 46, fig. 2. Type locality: Seas of India. SYNTYPES: AMS B.8236 $(1,133 \mathrm{~mm})$ and B.8237 $(1,81 \mathrm{~mm})$, both from Malabar. Remarks: Day did not provide details of the provenance of his specimens, except to say that the species was common at Bombay, and that a variety of the species was found in the Andamans and Orissa. Day listed his account of Sciaena dussumieri from Malabar (Day, 1865c) in the synonymy of the new species. It is possible that the specimens at AMS are the specimens he examined at that time.

Genyoroge grammica Day, 1871a: 679. Type locality: Andaman Is. SYNTYPE: AMS registration number unknown (1) Andamans. Remarks: Subsequent to the description of this species, Day (1875-78) placed the name in the synonymy of Lutianus quinquelinearis (Bloch). Day's packing list and the 1884 Annual Report list L. quinquelinearis, from the Andamans, among those shipped to AMS. However, no specimen identified as Lutianus quinquelinearis, L. quinquelineatus, or Genyoroge grammica from the Day collection was found in the AMS collection, and we have been unable to find an appropriate entry in the register. Thus, it is uncertain whether a specimen of this species was actually received by AMS.
Sicydium griseum Day, 1877a: 140. Type locality: South Canara. SYNTYPE: AMS B.8254 (1, $62 \mathrm{~mm})$ Canara. Remarks: Day indicated that he examined two specimens, of up to "3 inches" (76.2 mm) in length. Whitehead \& Talwar (1976) reported a second specimen of this species at ZSI.

Gobius griseus Day, 1876a: 285, pl. 63, fig. 3. Type locality: Madras, in the backwaters. SYNTYPE: AMS B.8300 (1,38 mm) Madras.

Barbus guentheri Day, 1869a: 582. Type locality: Hindree and Tamboodra rivers, Kurnool. NON-TYPES: AMS B.3039 (1, 135 mm, dry skin) Poona, India; AMS B.7518 (1, $160 \mathrm{~mm})$ Deccan. Remarks: Subsequent to the description of this species, Day (1875-78) placed this name into the synonymy of Barbus kolus Sykes. The AMS specimens arrived identified as Barbus kolus. The register entry for the specimen labelled AMS B.3039 listed "Poona", which is repeated in a gallery label associated with the specimen. The total length of this specimen (approximately $61 / 2$ inches ( $165.1 \mathrm{~mm}$ ), but caudal fin damaged) is larger than the range of sizes (" 2 to $53 / 10$ inches" ( 50.8 to $134.6 \mathrm{~mm}$ )) listed for the species originally examined by Day. The locality associated with AMS B.7518 is vague, but north of the type locality of the species. In addition, the specimen is much larger than that stated for the types. Thus, neither specimen qualifies as a type.

Mastacembelus guentheri Day, 1865a: 37. Type locality: Paddyfields and Trichoor backwater [Cochin]. NON-TYPE: AMS B.8048 (1, $224 \mathrm{~mm})$ Malabar. Remarks: This specimen was indicated in the register and in the 1884 Annual Report as a type, but in the description of the species Day (1865a) indicated that the specimens he examined ranged from $48 \% 10$ to 7 inches (121.9 to $177.8 \mathrm{~mm}$ ) in length. The largest specimen reported by Day is far shorter than the nearly 9 inch $(228.6$ $\mathrm{mm}$ ) standard length of the specimen at AMS.

Opsarius guttatus Day, 1870d: 620. Type locality: Irrawaddi, from Prome to Mandalay. SYNTYPE: AMS B.8224 (1, $138 \mathrm{~mm})$ Prome. Remarks: This specimen arrived at AMS identified as Barilius guttatus, following the nomenclature in Day (187578 ). Day indicated that he examined specimens up to "7 inches" $(177.8 \mathrm{~mm})$ in length.

Upeneoides guttatus Day, 1868b: 938. Type locality: Madras, India. SYNTYPE: AMS I.25 (1, $107 \mathrm{~mm})$ Madras. Remarks: Subsequent to the description of this species, Day (1875-78) placed the name in the synonymy of Upeneoides bensasi (Temminck \& Schlegel, 1843). The specimen at AMS was identified as $U$. bensasi and is from the type locality of $U$. guttatus. The size of the AMS specimen is consistent with the statement in the original description, which stated that the specimens examined by Day were up to " $47 / 10$ inches" (119.4 $\mathrm{mm}$ ) in length.

Mugil hamiltonii Day, 1870d: 614. Type locality: Irrawaddi, Pegu, and other rivers of Burma. SYNTYPE: AMS B.7993 (1,81 mm) Burma. Remarks: Day indicated that he examined specimens of up to " $4 \frac{1}{2}$ inches" (114.3 mm) in length. Thomson (1997: 497) identified this specimen as Sicamugil hamiltoni, but apparently did not consider it to be part of the type series.

Barbus (Barbodes) himalayanus Day, 1872b: 325. Type locality: Ussun River, about four miles from Simla. SYNTYPES: AMS B.7868 (2, 93-153 mm) Simla. Remarks: Day (1875-78) placed the name in the synonymy of Barbus chilinoides McClelland. The specimens that were sent to AMS were identified as Barbus chilinoides, from a locality that is vague, but consistent with the type locality of Day's species. Eschmeyer (1998) was in error in stating that the description was based on a single specimen. Day reported that five specimens were examined. These specimens represent a species of the genus Tor (Ferraris, pers. obs).

Crenidens indicus Day, 1873d: clxxxvi. Type locality: Kurrachi and Madras. Syntype: AMS B.8216 (1, $235 \mathrm{~mm})$ Sind. Remarks: Sind is the region of Pakistan that includes Karachi 
(Kurrachi). Day gave no indication of the number of specimens of this species that he examined, but stated that the largest was "12 inches" (304.8 mm) in length.

Cubiceps indicus Day, 1871a: 690. Type locality: Madras. NoNTYPES: AMS I.108 (1, $91 \mathrm{~mm})$, I.645 (1, $89 \mathrm{~mm})$, and B.8114 (1, $35 \mathrm{~mm}$, re-identified by J. Leis in 1996, as Lutjanus sp.), all from Madras. Remarks: These specimens were not indicated as types in the 1884 Annual Report, but the latter two (I.645 and B.8114) were so indicated in the register and card index. In his description of the species, Day (1871a) indicated that he had several specimens "up to 3 inches long" $(76.2 \mathrm{~mm})$. Two of the specimens listed here are over 4 inches $(101.6 \mathrm{~mm})$ in standard length, much larger than the maximum size indicated by Day. The third specimen (B.8114) is less than three inches (76.2 $\mathrm{mm}$ ), but is clearly not a specimen that fits Day's description. Therefore, the indications in the register that these specimens represent types appear to be incorrect.

Saurus indicus Day, 1873c: 526. Type locality: Madras. NON-TYPE: AMS B.7672 (1, $210 \mathrm{~mm})$ Madras. Remarks: Day indicated that he examined three specimens of this species, up to "7 inches" (177.8 mm) in length. Cressey (1981: 21) considered the AMS specimen to be as Saurida tumbil and not conspecific with the Leiden paralectotype, which he considered to be a specimen of Saurus indicus. See Eschmeyer (1998) for discussion about lectotype designation of this species.

Barilius interrupta Day, 1870b: 559. Type locality: Hotha [China]. SYNTYPE: AMS B.7745 (1, 46 mm) Hotha, Yunnan. Remarks: Day indicated that he examined specimens up to 2 inches (50.8 $\mathrm{mm}$ ) in total length.

Scaphiodon irregularis Day, 1872b: 324. Type locality: Rivers in the Sind Hills, up to 3500 feet elevation, and Marrí. SYNTYPE: AMS B.7883 (1, $79 \mathrm{~mm})$ Sind.

Barbus (Barbodes) jerdoni Day, 1870f: 372. Type locality: Mangalore. SYNTYPE: AMS B.7935 (1, 179 mm) Canara. Remarks: The locality stated for the specimen is the region of India that includes the city of Mangalore, the type locality of the species. Day did not indicate the number of specimens examined or the range of their lengths.

Garra jerdoni Day, 1867a: 288. Type locality: Seegoor and Bowany rivers. NON-TYPE: AMS B.7677 $(1,153 \mathrm{~mm})$ Bowany. Remarks: This specimen was received at AMS identified as Discognathus jerdoni, following the nomenclature in Day (1875-78). Day reported that he examined specimens ranging from " 2 to $45 / 10$ inches" (50.8 to $114.3 \mathrm{~mm}$ ) in total length. The AMS specimen is too large to be part of the type series.

Mugil jerdoni Day, 1876a: 352. Type locality: Seas of India. SYNTYPE: AMS B.7983 (1, 118 mm) Bombay. Remarks: Day provided little information on the provenance of his type specimens. At least part of his type series came from the vicinity of Cochin, where he had previously identified the specimens as Mugil sundanensis (Day, 1865b). The AMS specimen is considered a type on the basis of the identification provided on the original label.

Brachygramma jerdonii Day, 1865b: 304. Type locality: Cochin, India. NON-TYPE: AMS B.7871 (1, $161 \mathrm{~mm})$ Cochin. Remarks: Subsequent to the description of this species, Day placed the name in the synonymy of Amblypharyngodon melettinus (Valenciennes in Cuvier \& Valenciennes, 1844). A specimen identified as A. melettinus from the type locality of Brachygramma jerdonii was sent to AMS by Day. The original specimen label and the copy of that label are both absent from the jar, but the specimen has a metal tag sewn to its lower jaw. However, the specimen is far larger than the " $2 \% 10$ to $38 / 10$ inches" (73.7 to $96.5 \mathrm{~mm}$ ) that Day listed in the original description, and the specimen quite clearly does not match the description of this species. The Catalogue index card prepared for this species lists the size of the specimen as 4 inches $(101.6 \mathrm{~mm})$, which is about one half the total length of the specimen mentioned here. Thus, it appears that the specimen currently labelled as AMS B.7871 is not the specimen originally sent as Amblypharyngodon melettinus and cannot be considered a type of that species.

Mugil klunzingeri Day, 1888a: 264. Type locality: Red Sea and seas of India, and Bombay. SYNTYPES: AMS B.8078 (2, 104$109 \mathrm{~mm}$ ) Bombay. Remarks: This name was based on the specimens first identified as Mugil carinatus in Fishes of India (Day, 1877c: 349, pl. 74, fig. 2), which Day later determined was not that species. The AMS collection has two specimens from the Day collection identified as Mugil carinatus from Bombay, which must be considered as a part of the type series of Mugil klunzingeri.

Pomacentrus labiatus Day, 1877c: 384, pl. 81, fig. 2. Type locality: Andamans and Nicobars. SYNTYPE: AMS I.149 (1, $57 \mathrm{~mm})$ Andamans.

Trichogaster labiosus Day, 1877c: 374, pl. 79, fig. 4. Type locality: Burma, found in the Irrawaddi at Rangoon, and certainly as high as Mandalay. SYNTYPE: AMS B.7582 (1, $52 \mathrm{~mm}$ ) Burma. Remarks: The locality given for the specimen is vague, but it is consistent with the type locality of the species.

Tetrodon leopardus Day, 1878: 706, pl. 180, fig. 2. Type locality: Seas of India. SYNTYPE: AMS B.7722 (1) Madras.

Glyphidodon leucopleura Day, 1877c: 385, pl. 83, fig. 4. Type locality: Andamans. POSSIBLE SYNTYPE: AMS I.95 (1, $22 \mathrm{~mm}$ ) Andamans. Remarks: Day indicated that he examined two specimens during the preparation of this species account. A specimen identified as this species, from the type locality, was among those sent to AMS by Day. However, Whitehead \& Talwar (1976) report that both ZSI and NMW possess a specimen from the Day collection. Thus, the type status of one or more of the three specimens mentioned above is in question.

Petroscirtes lienardi Day, 1876a: 327, pl. 69, fig. 8. Type locality: Sind. SYNTYPE: AMS B.7984 (1) Sind. This specimen is listed in the register as lost in 1930.

Euglyptosternum lineatum Day, 1877c: 500, pl. 116, fig. 7. Type locality: Jumna River and near Suddya in upper Assam. SYNTYPE: AMS B.7509 (1, $266 \mathrm{~mm})$ Suddya. Remarks: The copy of the original label states "Euglyptosternum striatum Day". This appears to be a lapsus calami, either by Day or the person who transcribed Day's original label, for Euglyptosternum lineatum and not Glyptosternum striatum. Euglyptosternum lineatum was listed in Day's packing list as one of the species sent to AMS by Day; Glyptosternum striatum was not. The specimen referred to here is about $12 \frac{1}{2}$ inches $(317.5 \mathrm{~mm})$ in total length which, together with the locality listed on the label, appears to correspond to a specimen from Suddya mentioned specifically by Day in his description.

Barbus (Barbodes) lithopidos Day, 1874: 708. Type locality: South Canara. Syntype: AMS B.8374 (1, 277 mm) Canara; POSSIBLE SYNTYPES: AMS B.3029 (1, 285 mm, dry skin), AMS B.3030 (1, apparently a dry skin, destroyed in 1909). Remarks: One specimen, AMS B.8374, was listed as a type in the register and card file and is from the type locality of the species. The register entries for the remaining two specimens have very rudimentary notations, and no indication that either specimen was a type. However, a gallery label prepared for AMS B.3029 states the locality of the specimen as "Southern Canara, Western India." Thus, it is possible that this specimen is part of the type series of the species. The status of the remaining specimen (AMS B.3030) is moot, as the register indicates that the specimen was destroyed in 1909.

Glyptosternum madraspatanum Day, 1873c: 526. Type locality: Bowany River, at the base of the Neilgherry Hills. PossIBLE SYNTYPES: AMS B.7759 (1, $79 \mathrm{~mm})$ Bowany and B.8004 (1, $107 \mathrm{~mm}$ ) Bowany. Remarks: Day indicated that he examined 
five specimens of this species, the longest of which was "5 inches" $(127 \mathrm{~mm})$. The two specimens clearly represent different species of Glyptothorax.

Esomus (Nuria) maderaspatensis Day, 1867a: 300. Type locality: Bowany River and Madras. POSSIBLE SYNTYPE: AMS B.7831 (1, $48 \mathrm{~mm})$ Madras [but see below]. Remarks: Subsequent to the description of this species, Day (1875-78) placed the name in the synonymy of Nuria danrica (Hamilton). Specimens identified as Nuria danrica from Madras, Pegu, and Malabar were included in the specimens received at AMS. The locality recorded for this specimen in the register indicates that it was from Malabar and, therefore, a likely syntype of Esomus (Nuria) maderaspatensis. However, two original labels were found with the specimen in the jar: one indicating Madras as the locality of the specimen; the second indicating Pegu. Therefore, the type status of this species is uncertain.

Gobius madraspatensis Day, 1868c: 152. Type locality: Backwaters in Madras. POSSIBLE SYNTYPE: AMS B.8090 (1, $51 \mathrm{~mm})$ Madras. Remarks: Day indicated that he examined three specimens, from " $2 \% 1 / 10$ to 3 inches" ( 73.7 to $76.2 \mathrm{~mm}$ ) in total length. Whitehead \& Talwar (1976) report at least 10 other specimens, from ZSI and BMNH that, must be considered as possible type specimens.

Hara malabarica Day, 1865c: 184, pl. 13, fig. 3. Type locality: Mountain streams of Malabar, India. NON-TYPE: AMS B.7624 (1) South Canara. Remarks: This specimen was received at AMS as Macrones malabaricus, following the nomenclature in Day (1875-78). In the 1884 Annual Report, the specimen was indicated to be a type specimen, but Day apparently did not have any fish collections from South Canara until after 1867 (Day, 1870f). Therefore, this specimen cannot be considered as a type.

Carcharias malabaricus Day, 1873c: 529. Type locality: Palliport near Cochin, and Calicut on Malabar coast. SYNTYPE: AMS I.61 (1, 430 mm TL) Calicut. Remarks: Day indicated that he examined three specimens of this species, two of which were from Calicut. The Calicut specimens were said to be " 16 inches" $(406.4 \mathrm{~mm})$ in length, which is about one inch $(25.4 \mathrm{~mm})$ smaller than the length of the specimen at AMS. This specimen was identified as Carcharhinus dussumieri (Müller \& Henle, 1839) by Garrick (1982: 54).

Esomus malabaricus Day, 1867a: 299. Type locality: Trichoor in Malabar. POSSIBLE SYNTYPE: AMS B.7833 (1, $76.2 \mathrm{~mm})$ Malabar. Remarks: Subsequent to the description of this species, Day (1875-78) placed the name in the synonymy of Nuria danrica (Hamilton). The specimens arrived at AMS identified as $N$. danrica, from a locality consistent with the type locality of Esomus malabaricus. Day indicated that he examined specimens "up to 3 inches" $(76.2 \mathrm{~mm})$ in total length. The AMS specimen is approximately 3 inches $(76.2 \mathrm{~mm})$ in standard length and, therefore, probably too large to be one of the examined specimens.

Spratelloides malabaricus Day, 1873b: 240. Type locality: Sea, ascending rivers in Malabar. PARALECTOTYPE: AMS B.8288 $(1,44 \mathrm{~mm})$ Malabar. Remarks: Day indicated that he examined specimens of this species up to " 3 inches" $(76.2 \mathrm{~mm})$ in length. Talwar \& Whitehead (1971: 63) stated that the specimens examined by Day represented two species. They selected a ZSI specimen as lectotype, which they considered to represent a valid species in their new genus Dayella. The AMS specimen was of the second species, Ehirava fluviatilis (Deraniyagala).

Gobius masoni Day, 1873a: 107. Type locality: Bombay. SYNTYPE: AMS B.8089 (1, $75 \mathrm{~mm})$ Bombay.

Barbus mclellandi Day, 1870d: 619. Type locality: Pegu and Moulmein. SYNTYPES: AMS B.7741 (1), B.7742 (1), and B.7743 (1), each from Moulmein. Remarks: This name was preoccupied when Day treated Cyprinus mclellandi Valenciennes (in Cuvier \& Valenciennes, 1842) as a species of Barbus. Day (1871b) proposed Barbus (Puntius) stoliczkanus as a replacement. Three specimens identified as Barbus stoliczkanus, from the type locality of B. mclellandi, were included in the Day collection. An additional specimen identified as this species, AMS B.7542 (1) from Darjeeling, is not from the type locality and must, therefore, not be considered part of the type series. The species name was originally spelled mclellandi but changed to be consistent with Eschmeyer (1998).

Labeo melanampyx Day, 1865b: 298. Type locality: Mundikyum. NON-TYPE: AMS B.7556 (1, $21 \mathrm{~mm})$ Wynaad. Remarks: This specimen was received at AMS identified as Barbus melanampyx, following the nomenclature in Day (1875-78). However, the locality associated with the specimen is not the same as the stated type locality. Day (1867b) noted that he obtained specimens of this species from the Wynaad two years after the name Labeo melanampyx was published. Thus, this specimen is not part of the type series.

Gobius melanosticta Day, 1876a: 290, pl. 63, fig. 2. Type locality: Backwaters of Madras. SYNTYPE: AMS B.8202 (1, $31 \mathrm{~mm})$ Madras.

Atherina melanostigma Day, 1876a: 345. Type locality: Madras. SYNTYPE: AMS B.8357 (1, 58 mm) Madras. Remarks: Day reported specimens up to " 3 inches" (76.2 $\mathrm{mm}$ ) in length. This specimen was listed as a type in the AMS records, but was overlooked by Whitehead \& Talwar (1976).

Pseudosynanceia melanostigma Day, 1875: 163 (figured in Day [1876a] on pl. 55, fig. 6). Type locality: Kurrachee, in Sind. QUESTIONABLE TYPE: AMS B.8183 $(1,118 \mathrm{~mm})$ Kurrachee (Karáchi in annual report). Remarks: In the description of this species, Day stated that he obtained only one specimen (length 7 inches, $177.8 \mathrm{~mm}$ ). The AMS specimen is approximately $61 / 4$ inches $(156 \mathrm{~mm})$ in total length, and it bears a reasonable resemblance to the figure. However, there is also a specimen identified as this species at ZSI which has been regarded as the holotype (e.g., Eschmeyer 1998).

Ophichthys microcephalus Day, 1878: 665, pl. 170, fig. 2. Type locality: Malabar. SYNTYPE: AMS B.7843 (1, $634 \mathrm{~mm})$ Madras. Remarks: Day stated that he examined three specimens of this species, each at least "25 inches" $(635 \mathrm{~mm})$ in length.

Labeo microphthalmus Day, 1877c: 542, pl. 132, fig. 4. Type locality: Himalayas from Punjab, Murree, Kangra, also Cashmere. SYNTYPE: AMS B.7666 (1, $251 \mathrm{~mm})$ Himalayas. Remarks: This specimen was not listed as a type in the 1884 Annual Report, but the identification and locality of the specimen indicate that it should be so considered.

Macrones microphthalmus Day, 1877c: 446, pl. 100, fig. 4. Type locality: Burma along the valley of the Irrawaddi. SYNTYPE: AMS B.7918 (1, 169 mm) Burma. Remarks: Day provided no information regarding the number of specimens he examined, or their sizes. The locality associated with this specimen is vague, but consistent with the stated type locality of the species.

Mayoa modesta Day, 1870b: 553. Type locality: Northern India. POSSIBLE SYNTYPE: AMS registration number unknown, Assam. Remarks: This specimen was received at AMS as Discognathus modestus, following the nomenclature in Day (1875-78). In the original description of the species, Day indicated that he examined two specimens from northern India in the Calcutta Museum. He later repeated that information (Day, 1875-78), suggesting that he did not examine any additional specimens. However, Whitehead \& Talwar (1976) reported two specimens at ZSI, Calcutta (one of which was listed as missing) and two additional specimens from Day's collection in NMW, Vienna. In addition, the 1884 AMS annual report listed Discognathus modestus from Assam among the species received from Day. A search of the register, card file, and database has so far failed to turn up any record of this specimen. If found, that specimen may be the missing ZSI 
specimen, or another specimen of that species first examined by Day after publication of his Fishes of India.

Glyptosternum modestum Day, 1872d: 714. Type locality: Upper portion of Jumna [River]. SYNTYPES: AMS B.7562 (1, $64 \mathrm{~mm})$ Himalayas, AMS B.7564 (1, $61 \mathrm{~mm})$ Simla. Remarks: Subsequent to the description of this species, Day (1875-78) placed the name in the synonymy of Glyptosternum pectinopterum McClelland. One of the two specimens (AMS B.7564) arrived at AMS identified as G. pectinopterum. The other specimen (AMS B.7564) was identified as G. modestum, but that name was not shown in the packing list or annual report. The localities given for these specimens are consistent with the type locality of the species.

Barilius (Pachystomus) modestus Day, 1872a: 4. Type locality: Ravi River at Lahore. SYNTYPE AND NON-TYPE: AMS B.788485 (2, 73-100 mm) Punjab. Remarks: The Punjab is a region of western southern Asia that includes the city of Lahore. Therefore, the locality stated for the AMS specimen is consistent with the type locality of the species. However as Day indicated that he examined specimens up to "four inches" $(101.6 \mathrm{~mm})$ in length, this makes the larger of the two AMS specimens too large to be considered as a syntype.

Chatoessus modestus Day, 1870d: 622. Type locality: Bassein R., as high as Een-gay-gyee Lake [Burma]. PARALECTOTYPE: AMS B.7637 (1, $105 \mathrm{~mm})$ Burma. Remarks: Day indicated that many specimens up to " $5 \frac{1}{2} 2$ inches" (139.7 $\left.\mathrm{mm}\right)$ were examined. Talwar \& Whitehead (1971: 73) selected a ZSI specimen as lectotype and considered the species to be valid in Gonialosa. They claimed that the AMS specimen could not be a paralectotype, as they considered Day's description to be based on a single specimen. We find their reasoning flawed, for two reasons. Day clearly indicated that he examined more than one specimen, so his concept of the species was not based on a single individual. Also, by Talwar and Whitehead's reasoning, there should have been no need, and no justification, to select a specimen as lectotype if a single specimen (a holotype) was indicated.

Semiplotus modestus Day, 1870e: 101. Type locality: Hill ranges of Akyab. SYNTYPE: AMS B.7837 (1, 100 mm) Akyab. Remarks: Day indicated that he examined two specimens, of " $4 \frac{1}{2}$ to $5 \frac{1}{2}$ inches in length" ( 114.3 to $139.7 \mathrm{~mm}$ ). The size and locality information associated with this specimen is consistent with the information provided by Day. Whitehead \& Talwar (1976) stated that a second specimen from Day's collection is at ZSI.

Nemacheilus multifasciatus Day, 1878: 617, pl. 153, fig. 7. Type locality: Darjeeling and Assam. SYNTYPE: AMS B. 7737 (1, 59 $\mathrm{mm}$ ) Darjeeling. Remarks: Day provided no information on the number or size range of the specimens he examined.

Barbus nashii Day, 1869a: 584. Type locality: Fraserpett River, at base of the Coorg Hills, Coorg District. NON-TYPE: AMS B.7693 (1, $183 \mathrm{~mm})$ Canara. Remarks: This specimen was sent to AMS identified as Scaphiodon nashii (Day), but Day (1877c: 552) indicated that specimens from South Canara were not acquired by him until after publication of the name. Pethiyagoda \& Kottelat (1994: 104) treated this specimen as a syntype and considered it to represent a valid species of Osteochilichthys.

Paradanio neilgherriensis Day, 1867a: 296. Type locality: Ootacamund Lake, Pykara, Avelanche and Kaity streams. SYNTYPES: AMS B.7724 (1), AMS B.7725 (1), both from Ootacamund. Remarks: These specimens were received at AMS as Danio neilgherriensis, following the nomenclature in Day (1875-78). The standard length of these specimens is $43.6 \mathrm{~mm}$ and $52.1 \mathrm{~mm}$, however it is not possible to associate the registration numbers to either fish as the metal tags bearing these registration numbers are not attached to the fish, but are loose in the jar. Day indicated that he examined specimens up to " $3 \frac{1}{2} 2$ inches" $(88.9 \mathrm{~mm})$ in total length, therefore we consider these specimens to be syntypes.
Barbus neilli Day, 1869a: 581. Type locality: (?) Kurnool. Possible SynTyPE: AMS B.7870 (1,84 mm) Deccan. Remarks: Day did not clearly state a type locality of this species. He reported that it was "very common at Kurnool", but, by our reading, the species was more wide ranging.

Gobius neilli Day, 1868c: 152 . Type locality: Backwaters and along the sea-shore [India]. SYNTYPE: AMS B.8312 (1, $43 \mathrm{~mm})$ Madras. Remarks: The account of this species does not include information on the provenance of the specimens examined. Most of the species described in the same publication were from Madras, and it is likely that this species was also collected there. The original label associated with this specimen lists Madras as the locality, as do the 1884 Annual Report and Day's packing list. Day reported that the specimens ranged in size from " $15 / 10$ to $32 / 10$ inches" ( 38.1 to $81.3 \mathrm{~mm}$ ), but did not indicate how many specimens were examined.

Labeo neilli Day, 1870e: 99. Type locality: Sittoung and Billing [rivers, Burma]. POSSIBLE SYNTYPE: AMS B.8150 (1, $105 \mathrm{~mm})$ Burma. Remarks: This specimen was received at AMS as Osteocheilus neilli, following the nomenclature in Day (187578). The imprecise locality associated with the specimen is not inconsistent with that of the type locality of the species. However, Whitehead \& Talwar (1976) indicate there are at least 14 possible syntypes for this species (not including the one mentioned herein), even though only 7 specimens were mentioned in the original description and the account in Day (1875-78). The AMS specimen is shorter than the maximum size (6 inches, $152.4 \mathrm{~mm}$ ) of specimens examined by Day. Thus, the status of this specimen requires further investigation.

Callichrous nigrescens Day, 1870d: 616. Type locality: Throughout the branches of the Irrawaddi, in the Pegu and Sittoung rivers [Burma]. SYNTYPE: AMS B.7636 $(1,123)$ Burma. Remarks: Subsequent to the description of this species, Day (1875-78) placed this name into the synonymy of Callichrous pabo. This specimen was sent to AMS under that name. The locality associated with the specimen is vague, but not inconsistent with that of the type locality of the species. Day did not indicate how many specimens he examined, but stated that the largest specimen was " $61 / 2$ inches" ( $165.1 \mathrm{~mm})$, which is larger than the specimen sent to AMS.

Labeo nigrescens Day, 1870f: 371. Type locality: Mangalore. SYNTYPE: AMS B.7703 (1, $160 \mathrm{~mm})$ Mangalore. Remarks: Day did not provide any information on the number of specimens examined or the size range of the specimens.

Caranx nigripinnis Day, 1876a: 225, pl. 51, fig. 5. Type locality: Madras and Andamans. SYNTYPE: AMS B.8043 (1, $147 \mathrm{~mm})$ Madras.

Labeo nigripinnis Day, 1877c: 544, pl. 132, fig. 3. Type locality: Sind hills and rivers at their bases. SYNTYPE: AMS B.7842 (1, $88 \mathrm{~mm}$ ) Sind.

Barilius nigrofasciatus Day, 1870d: 620. Type locality: Pegu and Moulmein. SYNTYPE: AMS B.7558 (1, not measurable) Pegu. Remarks: This specimen arrived at AMS identified as Danio nigrofasciatus, following the nomenclature in Day (1875-78). The specimen is badly dehydrated and broken into pieces.

Callichrous notatus Day, 1870d: 616. Type locality: Rivers of Burma. SYNTYPE AND NON-TYPE: AMS B.7982 (2, 93-128 mm) Burma. Remarks: Subsequent to the description of this species, Day (1875-78) placed this name into the synonymy of Callichrous macrophthalmus $[\mathrm{sic},=$ Callichrous macrophthalmos] Blyth. These specimens were sent to AMS under that name. The locality associated with the specimens is vague, but no more so than the type locality of the species. Day did not indicate how many specimens he examined, but stated that the largest specimen was "4 inches" (101.6 mm). The larger of the two specimens at AMS is substantially longer than 4 inches and cannot, therefore, be considered a type. 
Dentex (Synagris) notatus Day, 1871a: 684. Type locality: Andamans. POSSIBLE HOLOTYPE: AMS B.8219 (1, $187 \mathrm{~mm})$ Andaman Is. Remarks: In the original description of the species, Day (1871a) stated that he had only one specimen of this species, but gave no indication of its size. The Zoological Survey of India lists one specimen in their catalogue (ZSI 229) which has been regarded as the holotype (e.g., Eschmeyer, 1998). However, because the AMS specimen is from the type locality, it must also be considered as the possible holotype.

Gobius ocellatus Day, 1873a: 107. Type locality: Bombay. SYNTYPE: AMS B.8055 (1, $107 \mathrm{~mm})$ Bombay. Remarks: Day indicated that he examined specimens of this species up to " $51 / 2$ inches" (139.7 mm) in length. This specimen was identified by Helen Larson in 1981 as Aulopareia ocellatus.

Pristipoma olivaceum Day, 1875: 73, pl. 19, fig. 1. Type locality: Coasts of Bealoochistan and Sind. SYNTYPE: AMS B.8335 (1, $187 \mathrm{~mm}$ ) Sind. Remarks: Day provided no information on the number of specimens of this species he examined. He indicated that the species attained "at least a foot in length", which is larger than the AMS specimen.

Sciaena osseus Day, 1876a: 193, pl. 46, fig. 3. Type locality: Malabar coast of India. PARALECTOTYPE: AMS B.8249 (1) Malabar. Remarks: The account of this new species was written in such a manner that it is not clear whether Day examined more than one specimen. However, the specimen was sent to AMS identified as Sciaena osseus, and is therefore considered to be part of the type series. Talwar (1971) selected a ZSI specimen as lectotype, but did not comment on the AMS specimen.

Chela panjabensis Day, 1872a: 25. Type locality: Lahore, in the Ravi River. SYNTYPE: AMS B.7732 (1, 45 mm) Lahore.

Barilius (Barilius) papillatus Day, 1869b: 378. Type locality: Cossye River [Orissa], and the Mahanuddi. SYNTYPE AND NON-TYPE: AMS B.7909 (2, 56-92 mm) Orissa. Remarks: After Day described the species, he placed the name in the synonymy of Barilius barna (Hamilton). The locality given for the specimens is consistent with the type locality. However, Day (1869b) indicated that the species grew to "3 inches in length" (76.2 $\mathrm{mm})$, which is substantially less than the length of the larger of the two specimens at AMS. Therefore, the smaller of the two specimens is considered a syntype, while the larger is not part of the type series.

Puntius parrah Day, 1865b: 301. Type locality: In rivers and inundated paddy-fields [Cochin, India]. SYNTYPE: AMS B.7840 $(1,70 \mathrm{~mm})$ Kurriavanoor. Remarks: This specimen was received at AMS identified as Barbus parrah, following the nomenclature in Day (1875-78). Day indicted that he examined specimens ranging in size from " $2 \% 10$ to 5 inches" ( 71.1 to $127 \mathrm{~mm}$ ). The locality listed for the specimen is a river in the vicinity of Cochin.

Gobius planiceps Day, 1876a: 296. Type locality: Madras. POSSIBLE SYNTYPE: AMS B.8286 (1, $33 \mathrm{~mm})$ Madras. Remarks: Day indicated that he examined specimens up to " $11 \frac{1}{2}$ inches" $(38.1 \mathrm{~mm})$ in length. If his measurements were recorded as total length, the AMS specimen would be too large to be considered a type, as it is nearly $1 \frac{1 / 2}{2}$ inches $(38.1 \mathrm{~mm})$ in standard length. We found the specimen dehydrated.

Nemacheilus pulchellus Day, 1873c: 528. Type locality: Bowany River. SYNTYPE: AMS B.7739 (1, 48 mm) Madras. Remarks: Day indicated that he examined 21 specimens of this species up to " $2 \frac{1}{2}$ inches" $(63.5 \mathrm{~mm})$ in length. The Bowany River is near Madras.

Ailiichthys punctata Day, 1872d: 713. Type locality: Jumna at and below Delhi, also lower Punjaub rivers. SYNTYPE: AMS B.7570 $(1,69 \mathrm{~mm})$ Delhi. Remarks: Day indicated that he examined specimens up to "4 inches" (101.6 mm) in length.

Nangra punctata Day, 1877c: 494, pl. 115, fig. 8. Type locality: Sone River at Bheer Bhoom. SYNTYPE: AMS B.7566 (1, 47 mm) Sone River. Remarks: Identified by Roberts \& Ferraris (1998: 334) as Gangra viridescens (Hamilton, 1822).
Puntius punctatus Day, 1865b: 302. Type locality: no specific location given [Cochin, India]. POSSIBLE SYNTYPE: AMS B.7746 $(1,41 \mathrm{~mm})$ Kurriavanoor. Remarks: This specimen was received at the AMS identified as Barbus punctatus, following the nomenclature in Day (1875-78). The locality listed for the specimen is a river in the vicinity of Cochin, the presumed type locality of the species. As Day reported that he examined specimens ranging in size from " $25 / 10$ to $34 / 10$ inches" (63.5 to $86.4 \mathrm{~mm}$ ), we consider this specimen to be a possible syntype.

Silurus punctatus Day, 1868c: 155. Type locality: Stream in Wynaad, about 3000 feet above sea level. SYNTYPE: AMS B.7990 (1, $131 \mathrm{~mm})$ Wynaad. Remarks: Silurus punctatus Day was preoccupied by Silurus punctatus Cantor, 1842, and replaced by Silurus wynaadensis (Day, 1873b). The 1884 Annual Report listed Silurus wynaadensis, from the type locality, among the species received. Day indicated that he examined specimens ranging from " 4 to $81 / 10$ inches" (101.6 to $205.7 \mathrm{~mm}$ ) in total length, but not the number of specimens. This specimen must also be considered a syntype of $S$. punctatus Day.

Barbus (Puntius) punjaubensis Day, 1871b: 334. Type locality: Ravi R. at Lahore. NON-TYPE: AMS B.7545 (1, 20 mm) Sind. Remarks: The AMS specimen is from Sind, a region of Pakistan that does not include Lahore, the type locality of this species.

Serranus radiatus Day, 1868a: 699. Type locality: Near Madras, India. POSSIBLE HOLOTYPE: AMS B.8342 (1, $79 \mathrm{~mm})$ Madras. Remarks: Subsequent to the description, Day (1875) placed the name in the synonymy of Serranus morrhua Valenciennes, 1833. The AMS specimen was sent identified as Serranus morrhua and the locality given for the specimen is the same as the type locality. The description of this species is written in a way that suggests that Day examined only one specimen of a total length of " 4 inches" ( $101.6 \mathrm{~mm})$. The size of the specimen is virtually the same $(80 \mathrm{~mm}$, vs. $79 \mathrm{~mm})$, and identically marked, as the specimen illustrated in Day (1875, pl. 5, fig. 3), which was said to be drawn at full size and captured in 1867 at Madras. Thus, it is possible that the AMS specimen is the illustrated specimen and holotype of Serranus radiatus, even though a specimen at the Zoological Survey of India (ZSI 1676) was considered by Whitehead \& Talwar (1976) to be the figured specimen.

Scomber reani Day, 1871a: 690. Type locality: Andamans. SYNTYPE: AMS B.8140 (1, $232 \mathrm{~mm})$ Andamans. Remarks: Subsequent to the description of this species, Day (1875-78) placed the name in the synonymy of Scomber microlepidotus Rüppell. This specimen arrived at AMS identified as $S$. microlepidotus, from the type locality of $S$. reani. Day reported that he examined specimens up to "12 inches" (304.8 mm).

Nemacheilus semiarmatus Day, 1867a: 286. Type locality: Bowany and Seegoor rivers, Billicul Lake, and Ootacamund. SYNTYPE: AMS B.7740 (1, $47 \mathrm{~mm})$ Bowany. Remarks: Day indicted that he examined specimens of this species up to " 4 inches" (101.6 $\mathrm{mm}$ ) in total length.

Nemacheilus serpentarius Day, 1870b: 551. Type locality: no locality stated. SYNTYPE: AMS registration number unknown. Remarks: Day proposed the name Nemacheilus serpentarius for three specimens he examined in the Calcutta Museum. At that time, he provided no indication of the provenance of the specimens. He later (Day, 1877c) placed that name into synonymy of Homaloptera bilineata Blyth and indicated that he had examined three specimens in the Calcutta Museum from the Tenasserim provinces. Whitehead \& Talwar (1976) reported two specimens of $N$. serpentarius registered at ZSI, but not found during their inventory. The 1884 Annual Report lists Homaloptera bilineata from Tenasserim among the species received from Day, but no specimen so identified has yet been found at AMS. If found, that specimen should be considered a syntype of Nemacheilus serpentarius.

Arius serratus Day, 1877c: 462, pl. 105, fig. 3. Type locality: Sind. NON-TYPE: AMS B.7971 (1, $127 \mathrm{~mm})$ Sind. Remarks: Day 
stated that he examined only one specimen in his description of this species. The specimen deposited at AMS was listed as a type in the 1884 Annual Report and Register and was from the type locality. However, Whitehead \& Talwar (1976) report that a specimen of this species from Day's collection is also registered at ZSI. In the description of the type specimen, Day did not include its size, but the illustration of the species was said to be full size, which would make the specimen approximately $95 \mathrm{~mm} \mathrm{SL}$, far smaller than the AMS specimen. Thus, it is unlikely that the AMS specimen is the holotype of the species. Kailola (1986) examined this specimen and also commented on the difficulty of assessing its type status. However, she identified the AMS specimen of Arius serratus as Arius bilineatus.

Cirrhina sindensis Day, 1872b: 319. Type locality: Sind Hills. SYNTYPE: AMS B.7661 (1, $158 \mathrm{~mm})$ Sind. Remarks: This specimen arrived at AMS identified as Labeo sindensis, following the nomenclature in Day (1875-78). Day indicated that the specimens he examined ranged to " 8 inches" $(203.2 \mathrm{~mm})$ in length.

Clupea sindensis Day, 1878: 638, pl. 163, fig. 2. Type locality: Seas of the Seychelles, Sind and Bombay. PARALECTOTYPE: AMS B.7642 (1, 113 mm) Bombay. Remarks: Talwar \& Whitehead (1971) treated this name as valid in Sardinella and selected a lectotype from a specimen at ZSI. They considered the AMS specimen a paralectotype and conspecific with the lectotype.

Glyphidodon sindensis Day, 1873d: cclxiii. Type locality: Kurrachi. SYNTYPE: AMS I.144 (1, 45 mm) Sind. Remarks: Day indicated that he examined specimens of this species up to " $41 \frac{1}{2}$ inches" $(114.3 \mathrm{~mm})$ in length. The locality stated for this specimen is an old spelling of Karachi, which is located within the region of Pakistan called Sind.

Chela sladoni Day, 1870d: 622. Type locality: Irrawaddi, as high as Mandalay [Burma]. SYNTYPE: AMS B.7852 (1, 86 mm) Prome. Remarks: Prome is a city on the Irrawaddy River, between the mouth of the river and Mandalay. Day indicated that the species was common, but he did not specify the lengths of the specimens examined.

Danio spinosus Day, 1870d: 621. Type locality: Pegu [Burma]. SYNTYPE: AMS B.7503 (1, $68 \mathrm{~mm})$ Burma. Remarks: Day stated that he examined four specimens, from $2^{1 / 2}$ to 4 inches (63.5 to $101.6 \mathrm{~mm}$ ) in length. This specimen was on loan and could not be examined.

Blennius steindachneri Day, 1873a: 110. Type locality: Kurrachee. SYNTYPE: AMS B.8003 (1, $83 \mathrm{~mm})$ Sind. Remarks: This specimen was not indicated as being a type specimen in the 1884 Annual Report, but is listed as a type in the AMS register. The locality given for the specimen is a region that includes the type locality for the species. Day indicated that he examined specimens of this species up to " 4 inches" $(101.6 \mathrm{~mm})$ in length.

Danio stoliczkae Day, 1870d: 621. Type locality: Moulmein, in tanks and streams [Burma]. SYNTYPES: AMS B.7646 (1, 39 $\mathrm{mm})$, B.7744 (1, $24 \mathrm{~mm})$, Moulmein, Burma. Remarks: Subsequent to the description of Danio stoliczkae, Day (187578 ) placed the name in the synonymy of $D$. albolineata. The specimens deposited at AMS were listed in Day's packing list as "Danio albolineata. Blyth. Moulmein (Blyth Type). Burma." The locality of these specimens is that of the type locality of Danio stoliczkae, from where Day collected "upwards of 100" specimens. These specimens are likely to be part of the type series of that species. However, Day (1870b: 558) noted that he examined 6 specimens of Muria [sic Nuria] albolineata in the Calcutta Museum from Moulmein, which may represent the type series of Blyth's name. It is possible that one or both of the AMS specimens may have come from this lot, as suggested by the wording of Day's packing list. However, the specimens in the Calcutta Museum were said to have been presented to the museum by a Mr Atkinson and not Major
Berdmore who, from the introductory remarks in Blyth's (1860) paper, was responsible for most of the specimens studied by Blyth. One further note: specimens catalogued as AMS B.77413 and AMS B.7542 were incorrectly listed as syntypes of this species in Eschmeyer (1998). The former are, instead, syntypes of Barbus (Puntius) stoliczkanus Day, and the latter is not from the type locality of that species and should therefore not be considered as a type of either Danio albolineata or Danio stoliczkae.

Exostoma stoliczkae Day, 1877b: 782. Type locality: Basgo, Sneema, and Leh or Ladak on the head-waters of the Indus. SYNTYPE: AMS I.122 (1, 126 mm) Indus. Remarks: Day indicated that he examined 17 specimens of this species ranging in length from 4 to 7 inches (101.6 to $177.8 \mathrm{~mm}$ ).

Serranus stoliczkae Day, 1875: 11, pl. 1, fig. 3. Type locality: Coast of Sind, common at Aden. PARAlectotype: AMS B.8157 (1, $157 \mathrm{~mm})$ Aden. Remarks: Day indicated that this species attained a length of "at least 12 inches" $(304.8 \mathrm{~mm})$. See Eschmeyer (1998) for information on lectotype designation.

Barbus (Puntius) stoliczkanus Day, 1871b: 328. Type locality: Pegu, Moulmein [Burma]. SYNTYPES: AMS B.7741 (1), B.7742 (1), B.7743 (1), all from Moulmein. Remarks: This name was proposed as a replacement for Barbus mclellandi Day, 1870d, which is preoccupied in Barbus by Cyprinus mclellandi Valenciennes (1842). The type series of Day's Barbus mclellandi are also types of his replacement name.

Cyprinodon stoliczkanus Day, 1872c: 258. Type locality: Stream at the village Joorun, and also at Lodai, along the edge of the Rann [Kachh, India]. SYNTYPES: AMS B.7730-7731 (2, 31$33 \mathrm{~mm}$ ) Cutch. Remarks: Subsequent to the description of this species, Day (1875-78) placed the name in the synonymy of Cyprinodon dispar (Rüppell). The specimens arrived at AMS identified as $C$. dispar with the locality listed as Cutch (apparently an alternate spelling of Kachh). Day indicated that he examined 28 specimens, up to " 1.6 inches" $(40.6 \mathrm{~mm})$ in length.

Euctenogobius striatus Day, 1868d: 272, unnumbered fig. Type locality: Backwaters around Madras, Conjeveram, and near Arcot. SYNTYPE: AMS B.8146 (1) Malabar. Remarks: A specimen arrived at AMS as Gobius striatus, following nomenclature in Day (1875-78). Day indicated that he examined specimens ranging from " 1 to 5 inches" ( 25.4 to $127 \mathrm{~mm}$ ) in length. The specimen was not found at AMS during this study.

Nemacheilus striatus Day, 1867b: 347. Type locality: Wynaad, at 3000 feet. SYNTYPE: AMS B.7487 (1, $48 \mathrm{~mm})$ Wynaad. Remarks: Day indicated that he examined specimens up to " $2 \frac{1}{2}$ inches" $(63.5 \mathrm{~mm})$ in length. This specimen was found in a dehydrated condition during this study.

Silundia sykesii Day, 1876b: 569. Type locality: Deccan and Kurnool. SYNTYPE: AMS B.8084 (1, 147 mm) Kurnool. Remarks: Day indicated that he examined one specimen from Kurnool "nearly 9 inches" $(228.6 \mathrm{~mm})$ in length and two from an unspecified part of the Deccan "up to 61/2 inches" (165.1 $\mathrm{mm})$. The AMS specimen is too short to be the Kurnool specimen, but its length is about that of the larger of the specimens without precise locality. Whitehead \& Talwar (1976) indicated that specimens from Day's collection were also deposited at ZSI and NMW, and that one or more of the specimens are said to be from the Kistna River.

Boleophthalmus tenuis Day, 1876a: 305, pl. 65, fig. 1. Type locality: Estuaries of Kurrachee. LECTOTYPE: AMS B.7618 (1, $121 \mathrm{~mm}$ ) Sind. PROBABLE PARALECTOTYPE: AMS B.8037 (1, $126 \mathrm{~mm}$ ) Sind. Remarks: Whitehead \& Talwar (1976) listed AMS B.8037 as Boleophthalmus tenuis. The lectotype was designated in Murdy (1989: 53), who considered the species to be valid, but in the genus Scartelaos. AMS B.8037 was considered by Murdy to be conspecific with the lectotype. However, Day's original list of shipped specimens indicates that only one specimen was sent to AMS, and the AMS register 
lists only one specimen of this species. The specimen labelled AMS B.8037 was originally entered in the register as Gobioides tenuis, another species described by Day (also from Sind). The specimen labelled AMS B.8037 is evidently not that species and it appears that Day unintentionally sent AMS a second specimen of Boleophthalmus tenuis as Gobioides tenuis (see account of that species for further details).

Gobioides tenuis Day, 1876a: 319, pl. 69, fig. 3. Type locality: Sind. NON-TYPE: AMS B.8037 (1, $126 \mathrm{~mm})$ Sind. Remarks: Day's packing list, the 1884 Annual Report, and the register all indicate that a specimen of this species, from the type locality, was sent to AMS. There are no longer any original labels associated with AMS B.8037, and the register entry for this number was overwritten to read Boleophthalmus tenuis. The specimen labelled as AMS B.8037 was identified in Murdy (1989) as Scartelaos tenuis (Day), a name based on Boleophthalmus tenuis Day and not Gobioides tenuis. Day's (1876a) account of Gobioides tenuis was unclear as to whether more than a single specimen was examined, and one specimen from Day's collection was registered in the ZSI collection (ZSI 2071), but said to be lost (Whitehead \& Talwar, 1976). It appears that Day accidentally sent a second specimen of Boleophthalmus tenuis to AMS as Gobioides tenuis.

Ambassis thomassi Day, 1870f: 369. Type locality: Calicut and Mangalore [Malabar Presidency]. SYNTYPE: AMS I.148 (1, $83 \mathrm{~mm}$ ) Malabar. Remarks: The locality associated with the specimen is vague, but it encompasses a broad region that includes the type locality.

Barbus (Barbodes) thomassi Day, 1874: 707. Type locality: South Canara. SYNTYPE: AMS I.139 (1, $158 \mathrm{~mm})$ Canara. NoNTYPES: AMS B.3061 (1, $720 \mathrm{~mm}$, dry skin) and B.3062. One specimen, AMS I.139, was listed in the register with a precise locality that is consistent with the type locality of the species. The register entries for the remaining two specimens have very rudimentary notations and no indication that either specimen was a type. A gallery label prepared for AMS B.3061 states the locality of the specimen as "Southern Canara, Western India." However, Day indicated that he examined specimens up to " 18 inches" $(457.2 \mathrm{~mm})$ in length, which is much less than the length of this specimen, thus excluding it from type status. The status of the remaining specimen (AMS B.3062) is moot, as the register indicates that the specimen was destroyed in 1936.

Scaphiodon thomassi Day, 1877c: 551, pl. 134, fig. 1. Type locality: South Canara. SYNTYPE: AMS B.7825 (1, $114 \mathrm{~mm})$ Canara. This specimen was examined by Pethiyagoda \& Kottelat (1994: 104) and considered to represent a valid species of Osteochilichthys.

Nemacheilus triangularis Day, 1865b: 295. Type locality: Hills at Mundikyum. QUESTIONABLE SYNTYPE: AMS B.7738 (1, 49 $\mathrm{mm}$ ) Travancore. This specimen was listed as a type in the 1884 Annual Report. However, the locality associated with the specimen is in the southern part of what is now Kerala, south of the type locality, which is near the city of Cochin near the northern part of Kerala State. It is more likely that this specimen was acquired by Day subsequent to his description of Nemacheilus triangularis.

Chela untrahi Day, 1869b: 381. Type locality: Mahanuddi. NoNTYPE: AMS B.7901 (1, $132 \mathrm{~mm})$ Mahanuddi. Remarks: Day indicated examining specimens up to " 5 inches" $(127 \mathrm{~mm})$ in total length, which is smaller than the size of the AMS specimen. Two additional specimens from the Day collection, AMS B.7783 (1, $82 \mathrm{~mm})$ Madras and AMS B.7784 (1, $118 \mathrm{~mm})$ Madras are also not considered part of the type series.

Clupea variegata Day, 1870d: 623. Type locality: Irrawaddi and its branches [Burma]. PARALECTOTYPE: AMS B.7676 (1, $158 \mathrm{~mm})$ Bassein. Remarks: Day indicated that he examined many specimens, up to "7 inches" (177.8 $\mathrm{mm})$ in length. Talwar \&
Whitehead (1971) selected a ZSI specimen as lectotype and considered the species to be valid in Gudusia. They claimed that the AMS specimen could not be a paralectotype, as they considered Day's description to be based on a single specimen. As discussed in the account of Chatoessus modestus, we disagree with their reasoning, and treat the AMS specimen as a paralectotype.

Puntius vittatus Day, 1865b: 303. Type locality: no specific locality stated [Cochin, India]. NON-TYPE: AMS B.7554 (1, $34 \mathrm{~mm})$ Madras. Remarks: Although this specimen was listed in Whitehead \& Talwar (1976) as a possible type specimen, the locality associated with the specimen is not close to Cochin.

Barbus (Puntius) waageni Day, 1872b: 325. Type locality: Chua Saidar Shah, Salt Range [Pakistan]. SYNTYPE: AMS B.7632 (1, $39 \mathrm{~mm})$ Salt Range. Remarks: Day indicated that he examined specimens up to " $2 \frac{1 / 2}{2}$ inches" $(63.5 \mathrm{~mm})$ in length.

Scaphiodon watsoni Day, 1872b: 324. Type locality: Sind Hills. SYNTYPE: AMS B.7751 (1, $107 \mathrm{~mm})$ Sind. Remarks: Day gave no indication of the number, or sizes, of the specimens examined.

Barbus (Barbodes) wynaadensis Day, 1873c: 528. Type locality: Vithry [Wynaad, India]. PARALECTOTYPE: AMS B.7989 (1, $140 \mathrm{~mm}$ ) Wynaad. Remarks: Day indicated that he examined upwards of 40 specimens of this species, up to "8 inches" (203.2 $\mathrm{mm}$ ) in length. See Eschmeyer (1998) for information on lectotype designation.

Silurus wynaadensis Day, 1873b: 237. Type locality: Stream in Wynaad, about 3000 feet above sea level. SYNTYPE: AMS B.7990 (1, $131 \mathrm{~mm})$ Wynaad. Remarks: Silurus wynaadensis was proposed as a replacement name for Silurus punctatus Day, $1868 \mathrm{c}$, (which is preoccupied by Silurus punctatus Cantor, 1842) and, therefore, takes the same specimen as type.

ACKNOWLEDGMENTS. Financial support for this project came from a Collection Fellowship at the Australian Museum to the senior author. Assistance with literature and archival documents housed at the Australian Museum Library was provided by Leone Lemmer, Jan Brazier and Ann Pinson. Several staff members at the New South Wales State Library provided us with valuable assistance in locating and copying documents from Edward Ramsay's correspondence archives. Finally, Jeff Leis, John Paxton, and Doug Hoese all provided advice and information about the AMS fish collection, and encouraged us in our efforts. Without the assistance from the people and organizations listed here, it would not have been possible to complete this study. However, we alone take responsibility for any errors of omission or commission.

\section{References}

Anderson, J., [1879]. Anatomical and zoological researches: comprising an account of the zoological results of the two expeditions to western Yunnan in 1868 and 1875; and a monograph of the two cetacean genera, Platanista and Orcella. London: Bernard Quaritch. [Publication date corrected from 1878 in published corrigenda.]

Anon., 1885. Australian Museum (Report of the Trustees for 1884). Government Printer, Sydney. Pp. 46.

Anon., 1886. Australian Museum (Report of the Trustees for 1885). Government Printer, Sydney. Pp. 47.

Bleeker, P., 1849. Bijdrage tot de kennis der Blennioïden en Gobioïden van der Soenda-Molukschen Archipel, met beschrijving van 42 nieuwe soorten. Verh. Batav. Genootsch. Kunst. Wet. v. 22: 1-40.

Bleeker, P., 1875. Atlas ichthyologique des Indes Orientales Neerlandaises, publie' sous les auspices du Gouvernement colonial neerlandais. Tome VIII (Percoides II, (Spariformes), 
Bogodoides, Cirrhiteoides). Pp. 156, pls. 321-354, 261-362.

Blyth, E., 1860. Report on some fishes received chiefly from the Sitang River and its tributary streams, Tenasserim Provinces. Journal of the Asiatic Society of Bengal 29(2): 138-174.

Cressey, R., 1981. Revision of Indo-west Pacific lizardfishes of the genus Synodus (Pisces: Synodontidae). Smithsonian Contributions to Zoology 342: 1-53.

Cuvier, G., \& A. Valenciennes, 1842 (August). Histoire naturelle des poissons. Tome seizième. Livre dix-huitième. Les Cyprinoïdes. v. 16: i-xx + 1-472, pls. 456-487. [Valenciennes authored volume. i-xviii $+1-363$ in Strasbourg edition.]

Cuvier, G., \& A. Valenciennes, 1844 (July). Histoire naturelle des poissons. Tome dix-septième. Suite du livre dix-huitième. Cyprinoïdes. V. 17: i-xxiii + 1-497 + 2 pp., pls. 487-519. [Valenciennes authored volume. $\mathrm{i}-\mathrm{xx}+1-370$ in Strasbourg edition.]

Day, F., 1865a. On the fishes of Cochin, on the Malabar coast of India. Part I. Acanthopterygii. Proceedings of the Zoological Society of London 1865(1): 2-40.

Day, F., 1865b. On the fishes of Cochin, on the Malabar Coast of India. Part II. Anacanthini. Proceedings of the Zoological Society of London 1865(1): 286-318.

Day, F., 1865c. The fishes of Malabar. Bernard Quaritch, London. Pp. i-xxxii + 1-293, pls. 20.

Day, F., 1867a. On the fishes of the Neilgherry Hills and rivers around their bases. Proceedings of the Zoological Society of London 1867(2): 281-302.

Day, F., 1867b. On some fishes from the Wynaad. Proceedings of the Zoological Society of London 1867(2): 347-350.

Day, F., 1868a. On some new or imperfectly known fishes of India. Proceedings of the Zoological Society of London 1867(3): 699-707.

Day, F., 1868b. On some new or imperfectly known fishes of India. Proceedings of the Zoological Society of London 1867(3): 935-942.

Day, F., 1868c. On some new or imperfectly known fishes of India. Proceedings of the Zoological Society of London 1868(1): 149-156.

Day, F., 1868d. On a new gobioid fish from Madras. Proceedings of the Zoological Society of London 1868(2): 272-273.

Day, F., 1869a. Observations on Indian fishes. Proceedings of the Zoological Society of London 1868(3): 580-585.

Day, F., 1869b. On the fishes of Orissa-Part II. Proceedings of the Zoological Society of London 1869(2): 369-387.

Day, F., 1870a. Remarks on some of the fishes in the Calcutta Museum-Part I. Proceedings of the Zoological Society of London 1869(3): 511-527.

Day, F., 1870b. Remarks on some fishes in the Calcutta MuseumPart II. Proceedings of the Zoological Society of London 1869(3): 548-560.

Day, F., 1870c. On some of the fishes in the Calcutta MuseumPart III. Proceedings of the Zoological Society of London 1869(3): 611-614.

Day, F., 1870d. On the freshwater fishes of Burma-Part I. Proceedings of the Zoological Society of London 1869(3): 614-623.

Day, F., 1870e. On the freshwater fishes of Burmah-Part II. Proceedings of the Zoological Society of London 1870(1): 99-101.

Day, F., 1870f. Notes on some fishes from the western coast of India. Proceedings of the Zoological Society of London 1870(2): 369-374.

Day, F., 1871a. On the fishes of the Andaman Islands. Proceedings of the Zoological Society of London 1870(3): 677-705.

Day, F., 1871b. Monograph of Indian Cyprinidae. Part II. Journal of the Asiatic Society of Bengal 40(2): 277-367.

Day, F., 1872a. Monograph of Indian Cyprinidae. Part IV. Journal of the Asiatic Society of Bengal 41(2): 1-29.
Day, F., 1872b. Monograph of Indian Cyprinidae. Part VI. Journal of the Asiatic Society of Bengal 41(2): 318-326, pl. 1.

Day, F., 1872c. Notes on fish, collected by Dr. Stoliczka in Kachh. Journal of the Asiatic Society of Bengal 41(2): 258-260.

Day, F., 1872d. On the freshwater siluroids of India and Burmah. Proceedings of the Zoological Society of London 1871(3): 703-721.

Day, F., 1873a. On some new or imperfectly known fishes of India and Burma. Proceedings of the Zoological Society of London 1873(1): 107-112.

Day, F., 1873b. On new or imperfectly known fishes of India. Proceedings of the Zoological Society of London 1873(1): 236-240.

Day, F., 1873c. On some new fishes of India. Journal of the Linnean Society of London, Zoology 11: 524-530.

Day, F., 1873d. Sea-fishes of India and Burma. In Report on the sea fish and fisheries of India and Burma, pp. cliii-cccxxxii. Calcutta.

Day, F., 1874. On some new or little-known fishes of India. Proceedings of the Zoological Society of London 1873(3): 704-710.

Day, F., 1875. The fishes of India; being a natural history of the fishes known to inhabit the seas and fresh waters of India, Burma, and Ceylon. Part 1: 1-168, pls. 1-40. London: Bernard Quaritch.

Day, F., 1875-78. The fishes of India; being a natural history of the fishes known to inhabit the seas and fresh waters of India, Burma, and Ceylon. London: Bernard Quaritch. Pp. 779, pls. 195.

Day, F., 1876a. The fishes of India; being a natural history of the fishes known to inhabit the seas and fresh waters of India, Burma, and Ceylon. Part 2: 169-368, pls. 41-78. London: Bernard Quaritch.

Day, F., 1876b. On some of the fishes of the Deccan. Journal of the Linnean Society of London 12(no. 64): 565-578.

Day, F., 1877a. Geographical distribution of Indian freshwater fishesPart I. The Acanthopterygii, spiny-rayed, Teleostean fishes. Journal of the Linnean Society of London 13(67): 138-154.

Day, F., 1877b. On the fishes of Yarkand. Proceedings of the Zoological Society of London 1876(4): 781-807.

Day, F., 1877c. The fishes of India; being a natural history of the fishes known to inhabit the seas and fresh waters of India, Burma, and Ceylon. Part 3: 369-552, pls. 79-138. London: Bernard Quaritch.

Day, F., 1878. The fishes of India; being a natural history of the fishes known to inhabit the seas and fresh waters of India, Burma, and Ceylon. Part 4: i-xx + 553-779, pls. 139-195. London: Bernard Quaritch.

Day, F., 1883. Catalogue of the exhibits in the Indian Section. In Great International Fisheries Exhibition, London, 1883, anonymous editor, pp. 198. London: G. Norman \& Sons.

Day, F., 1888a. Observations on the fishes of India-Part I. Proceedings of the Zoological Society of London 1888(3): 258-265.

Day, F., 1888b. The fishes of India; being a natural history of the fishes known to inhabit the seas and fresh waters of India, Burma, and Ceylon. Supplement: 779-816. London: Bernard Quaritch.

Day, F., 1889a. Fishes. In The fauna of British India, including Ceylon and Burma, ed. W.T. Blanford, vol. 1, pp. xviii +548 . London: Taylor and Francis; Calcutta: Thacker, Spink \& Co.; Bombay: Thacker \& Co.; and Berlin: R. Friedländer \& Sohn.

Day, F., 1889b. Fishes. In The fauna of British India, including Ceylon and Burma, ed. W.T. Blanford, vol. 2, pp. xiv +509 . London: Taylor and Francis; Calcutta: Thacker, Spink \& Co.; Bombay: Thacker \& Co.; and Berlin: R. Friedländer \& Sohn.

Eschmeyer, W.N. (ed.), 1998. Catalog of Fishes. San Francisco: California Academy of Sciences. Pp. 2905.

Garrick, J.A.F., 1982. Sharks of the genus Carcharhinus. National Oceanic and Atmospheric Administration Technical Report, 
National Marine Fisheries Service Circular 445: i-vii, 1-194. Gon, O., [1997]. Revision of the cardinalfish subgenus Jaydia (Perciformes, Apogonidae, Apogon). Transactions of the Royal Society of South Africa 51: 147-194. [Publication date corrected from 1996, on information provided by M.E. Anderson (pers. comm.)]

Kailola, P.J., 1986. Ariid systematics: comparison of the giant sea catfishes Arius thalassinus and A. bilineatus of the Indo-Pacific. In Indo-Pacific Biology: Proceedings of the Second International Conference on Indo-Pacific Fishes, eds. T. Uyeno, R. Arai, T. Taniuchi and K. Matsuura, pp. 540-549. Tokyo: Ichthyological Society of Japan.

Müller, J., \& F.G.J. Henle, 1838-41. Systematische Beschreibung der Plagiostomen. Berlin. i-xxii $+1-200,60$ pls. [Pp. 1-28 published in 1838, reset pp. 27-28, 29-102 in 1839, i-xxii + 103-200 in 1841.]

Murdy, E.O., 1989. A taxonomic revision and cladistic analysis of the oxydercine gobies (Gobiidae: Oxyderciniae). Records of the Australian Museum, Supplement 11: 1-93.

Nelson, J.S., 1994. Fishes of the World, third edition. New York, etc., John Wiley \& Sons, Inc. Pp. 600.

Paxton, J.R., \& M.A. McGrouther, 1996. A history of the fish collection at the Australian Museum (1860-1968), with a summary of current Australian fish collections. In Collection Building in Ichthyology and Herpetology, eds. T.W. Pietsch and W.D. Anderson Jr., pp. 183-205. American Society of Ichthyologists and Herpetologists, Special Publication Number 3.

Pethiyagoda, R., \& M. Kottelat, 1994. Three new species of the genera Osteocheilichthys (Cyprinidae), Travancoria (Balitoridae) and Horabagrus (Bagridae) from the Chalakudy River, Kerala, India. Journal of South Asian Natural History 1(1): 97-116.

Randall, J.E., \& P.C. Heemstra, 1991. Revision of Indo-Pacific groupers (Perciformes: Serranidae: Epinephelinae), with descriptions of five new species. Indo-Pacific Fishes 20: 1-332.
Roberts, T.R., 1994. Systematic revision of Asian bagrid catfishes of the genus Mystus senus stricto, with a new species from Thailand and Cambodia. Ichthyological Explorations of Freshwaters 5(3): 241-256.

Roberts, T.R., \& C.J. Ferraris Jr., 1998. Review of South Asian sisorid catfish genera Gagata and Nangra, with descriptions of a new genus and five new species. Proceedings of the California Academy of Sciences 50(14): 315-345.

Springer, V.G., \& J.T. Williams, 1994. The Indo-west Pacific blenniid fish genus Istiblennius reappraised: a revision of Istiblennius, Blenniella, and Paralticus, new genus. Smithsonian Contributions to Zoology 565: 1-193.

Talwar, P.K., 1971. The generic relationship and identity of Sciaena osseus Day, 1876 (Pisces: Sciaenidae). Journal of the Marine Biological Association of India 11: 324-328.

Talwar, P.K., \& P.J.P. Whitehead, 1971. The clupeoid fishes described by Francis Day. Bulletin of the British Museum (Natural History), Zoology 22(2): 59-85, pls. 1-2.

Temminck, C.J., \& H. Schlegel, 1843 (11 February) Pisces. In: Fauna Japonica, sive descriptio animalium quae in itinere per Japoniam suscepto annis 1823-30 collegit, notis observationibus et adumbrationibus illustravit P.F. de Siebold. Parts 2-4: 21-72.

Thomson, J.M., 1997. The Mugilidae of the World. Memoirs of the Queensland Museum 41(3): 457-562.

Whitehead, P.J.P., \& P.K. Talwar, 1976. Francis Day (1829-1889) and his collections of Indian fishes. Bulletin of the British Museum (Natural History), Historical Series 5(1): 1-189, pls. 1-4.

Manuscript received 17 September 1999, revised and accepted 30 March 2000

Associate Editor: J.M. Leis. 


\section{Appendix}

Nominal species names proposed by Francis Day that are represented by specimens at the Australian Museum, sorted by current family. Sequence of family names follows Nelson (1994).

Carcharinidae

Carcharias malabaricus

Ophichthyidae

Ophichthys microcephalus

Clupeidae

Chatoessus modestus

Clupea sindensis

Clupea variegata

Spratelloides malabaricus

Cyprinidae

Barbus ambassis

Barbus arenatus

Barbus bovianicus

Barbus burmanicus

Barbus (Barbodes) dobsoni

Barbus dukai

Barbus guentheri

Barbus (Barbodes) himalayanus

Barbus (Barbodes) jerdoni

Barbus (Barbodes) lithopidos

Barbus mclellandi

Barbus nashii

Barbus neilli

Barbus (Puntius) punjaubensis

Barbus (Puntius) stoliczkanus

Barbus (Barbodes) thomassi

Barbus (Puntius) waageni

Barbus (Barbodes) wynaadensis

Barilius bakeri

Barilius (Pachystomus) bleekeri

Barilius evezardi

Barilius interrupta

Barilius (Pachystomus) modestus

Barilius nigrofasciatus

Barilius (Barilius) papillatus

Brachygramma jerdonii

Chela argentea

Chela boopis

Chela panjabensis

Chela sladoni

Chela untrahi

Cirrhina sindensis

Dangila burmanica

Danio spinosus

Danio stoliczkae

Esomus (Nuria) maderaspatensis

Esomus malabaricus

Garra jerdoni

Labeo denisonii

Labeo melanampyx

Labeo microphthalmus

Labeo neilli

Labeo nigrescens

Labeo nigripinnis

Mayoa modesta

Opsarius guttatus

Paradanio neilgherriensis

Perilampus aurolineatus

Puntius (Barbodes) dubius

Puntius parrah

Puntius punctatus

Puntius vittatus

Rohtee bakeri

Scaphiodon irregularis

Scaphiodon thomassi

Scaphiodon watsoni

Semiplotus brevidorsalis
Semiplotus modestus

Balitoridae

Nemacheilus chryseus

Nemacheilus denisoni

Nemacheilus multifasciatus

Nemacheilus pulchellus

Nemacheilus semiarmatus

Nemacheilus serpentarius

Nemacheilus striatus

Nemacheilus triangularis

Bagridae

Hara malabarica

Macrones armatus

Macrones bleekeri

Macrones microphthalmus

Olyra burmanica

Pseudobagrus chryseus

Siluridae

Callichrous egertonii

Callichrous nigrescens

Callichrous notatus

Silurus dukai

Silurus punctatus

Silurus wynaadensis

Schilbidae

Ailiichthys punctata

Pseudeutropius acutirostris

Silundia sykesii

Sisoridae

Euglyptosternum lineatum

Exostoma andersonii

Exostoma stoliczkae

Glyptosternum madraspatanum

Glyptosternum modestum

Nangra buchanani

Nangra punctata

Clariidae

Clarias assamensis

Ariidae

Arius acutirostris

Arius andamanensis

Arius burmanicus

Arius serratus

Synodontidae

Saurus indicus

Mugilidae

Mugil hamiltonii

Mugil jerdoni

Mugil klunzingeri

Atherinidae

Atherina melanostigma

Aplocheilidae

Panchax argenteus

Cyprinodontidae

Cyprinodon stoliczkanus

Mastacembelidae

Mastacembelus guentheri

Scorpaenidae

Pseudosynanceia melanostigma

Scorpaena bleekeri

Ambassidae

Ambassis thomassi

Serranidae

Serranus coromandelicus

Serranus radiatus

Serranus stoliczkae

Apogonidae
Apogon ellioti

Carangidae

Caranx bidit

Caranx nigripinnis

Lutjanidae

Genyoroge grammica

Haemulidae

Pristipoma olivaceum

Sparidae

Chrysophrys cuvieri

Crenidens indicus

Nemipteridae

Dentex (Synagris) notatus

Sciaenidae

Otolithus brunneus

Sciaena glaucus

Sciaena osseus

Mullidae

Upeneoides fasciolatus

Upeneoides guttatus

Cichlidae

Etroplus canarensis

Pomacentridae

Glyphidodon leucopleura

Glyphidodon sindensis

Pomacentrus labiatus

Blenniidae

Blennius steindachneri

Petroscirtes lienardi

Salarias alboguttatus

Salarias andamensis

Eleotridae

Eleotris canarensis

Gobiidae

Amblyopus buchanani

Apocryptes bleekeri

Apocryptes cantoris

Boleophthalmus glaucus

Boleophthalmus tenuis

Euctenogobius cristatus

Euctenogobius striatus

Gobioides tenuis

Gobius andamanensis

Gobius griseus

Gobius madraspatensis

Gobius masoni

Gobius melanosticta

Gobius neilli

Gobius ocellatus

Gobius planiceps

Sicydium griseum

Scombridae

Scomber reani

Ariommatidae

Cubiceps indicus

Belontiidae

Trichogaster labiosus

Soleidae

Solea elongata

Cynoglossidae

Cynoglossus buchanani

Cynoglossus dispar

Tetraodontidae

Tetrodon leopardus 